\title{
Long-lasting Expression of JUN and KROX Transcription Factors and Nitric Oxide Synthase in Intrinsic Neurons of the Rat Brain following Axotomy
}

\author{
Thomas Herdegen, ${ }^{1}$ Stephan Brecht, ${ }^{1}$ Bernd Mayer, ${ }^{2}$ John Leah, ${ }^{3}$ Wolfgang Kummer, ${ }^{4}$ Rodrigo Bravo, ${ }^{5}$ and \\ Manfred Zimmermann' \\ 1l. Physiologisches Institut, Universität Heidelberg, 6900 Heidelberg, Germany, ${ }^{2}$ Institut für Pharmakologie and Toxikologie \\ Universität Graz, $8010 \mathrm{Graz}$, Austria, ${ }^{3}$ School of Science, Griffith University, Nathan 4111, Australia, ${ }^{4}$ Institut für Anatomie \\ und Zellbiologie, Universität Marburg, 3550 Marburg, Germany, and ${ }^{5}$ Department for Molecular Biology, Bristol-Myers \\ Squibb Pharmaceutical Research Institute, Princeton, New Jersey, 08543
}

In adult rats, the medial forebrain bundle (MFB) and mammillothalamic tract (MT) were unilaterally transected, resulting in axotomy of neurons in numerous areas such as the substantia nigra (SN), ventral tegmental area (VTA), nucleus (ncl.) mammillaris (MnM), and ncl. parafascicularis of the thalamus (PF). In these areas, expression of the transcription factor proteins C-JUN, JUN B, JUN D, c-FOS, FOS B, KROX20, KROX-24, and CREB was investigated by immunocytochemistry up to $150 \mathrm{~d}$. In parallel, the expression of nitric oxide synthase (NOS) was investigated both immunocytochemically and by the NADPH-diaphorase reaction (NDP), and the antibody against NOS was further characterized. The colocalization of c-JUN with NDP or NOS was also studied in the axotomized neurons.

c-JUN and JUN D became visible in nuclei of many neurons of the ipsilateral MnM, PF, VTA, and SN (predominantly in the pars compacta and those double labeled by tyrosine hydroxylase, TH) after $36 \mathrm{hr}$, not after $24 \mathrm{hr}$, following transection of MFB and MT. In MnM, c-JUN and JUN D persisted at a nearly maximal level for up to $150 \mathrm{~d}$. In PF, these proteins returned to control levels after $75 \mathrm{~d}$. Expression of c-JUN and JUN D declined in the VTA after $30 \mathrm{~d}$, but in the SN, it already declined after only $10 \mathrm{~d}$. KROX-24 had a later onset of expression, being visible after $3 \mathrm{~d}$ in all investigated areas, and its pattern was similar to that of JUN proteins, although labeling was visible in fewer nuclei and declined earlier. JUN B, C-FOS, FOS B, and KROX-20 were not expressed in these areas, and substantial alterations of CREB immunoreactivity (CREB-IR) could not be detected.

A subset of SN neurons (predominantly in the pars reticularis and negative for TH) presented an early and transient expression of all studied JUN, FOS, and KROX-24 proteins within $3 \mathrm{hr}$ of transection that declined between $24 \mathrm{hr}$ and $48 \mathrm{hr}$ to basal levels. This expression pattern is typical of that caused by transynaptic stimulation (probably due to excitation of descending striatal neurons running within the

\footnotetext{
Received Oct. 23, 1992; revised Feb. 25, 1993; accepted Apr. 7, 1993.

We thank Mrs. Anja Buhl and Mrs. Almuth Manisali for excellent technical assistance. This work was supported by the Deutsche Forschungsgemeinschaft, Grant Zi 110/22-1.

Correspondence should be addressed to Thomas Herdegen, II. Institute of Physiology, Im Neuenheimer Feld 326, 6900 Heidelberg, Germany.

Copyright (C) 1993 Society for Neuroscience $0270-6474 / 93 / 134130-16 \$ 05.00 / 0$
}

MFB) and was clearly distinct from that evoked by c-JUN, JUN D, and KROX-24 IRs after $36 \mathrm{hr}$ (predominantly in the pars compacta).

An ipsilateral increase in NOS and NDP became visible in many neurons of the $\mathrm{MnM}$ after $10 \mathrm{~d}$, but not after $\mathbf{5} \mathrm{d}$, and this persisted up to $150 \mathrm{~d}$. The temporospatial pattern of NDP was similar to the pattern of NOS-IR. In the MnM, 78$92 \%$ of neurons with NDP and $67-81 \%$ of neurons with NOSIR were also labeled for C-JUN. NOS-IR and NDP did not change in VTA and SN and remained absent in PF.

These results indicate that axotomized intrinsic neurons of CNS show either individual transient or long-lasting changes of transcription factors that may underlie and mediate their different sprouting potencies. The particular persistence and lasting coexpression of C-JUN and NOS in MnM neurons indicate a protective role of NOS and c-JUN partnership for damaged neurons in the rat CNS.

[Key words: axotomy, transcription factors, JUN proteins, FOS proteins, KROX proteins, nitric oxide, nitric oxide synthase, central intrinsic neurons, regeneration, regenerative potency, NADPH-diaphorase reaction]

Neurons of mammalian CNS respond to lesions of their axons with an intense cell body response, and with selective changes in gene expression (Mikucki and Oblinger, 1991; Tetzlaff et al., 1991). The extracellular matrix and glial environment have been shown to be crucial for the control of axonal sprouting of the damaged neurons (David and Aguayo, 1981; Villegaz-Perez et al., 1988; Schnell and Schwab, 1990; Wictorin et al., 1990; Bastmeyer et al., 1991; David et al., 1991). In addition to these extraneuronal components, intrinsic properties of neurons contribute to the potency of the cell body response and axonal sprouting (Richardson et al., 1984; Carpenter et al., 1986; Lyon and Stelzner, 1987; Davies, 1989; Fawcett, 1992). These intrinsic properties could depend on a differential control of those genes that precede and underlie the cell body response. However, at present nothing is known about the nuclear molecular genetic mechanisms of damaged neurons that initiate and maintain axonal sprouting. We have investigated the expression of JUN proteins (c-JUN, JUN B, and JUN D) in axotomized neurons because these transcriptionally operating proteins are supposed to play a crucial role in cellular growth, differentiation, and restoration (Nakabeppu et al., 1988; Ryder and Nathans, 
1988; Ryseck et al., 1988; Hirai et al., 1989; Hsu et al., 1992; Kovary and Bravo, 1992). Recently, we have shown that selective changes in the expression of c-JUN, JUN D, and CREB transcription factors precede the onset of the cell body response, and persist during the sprouting efforts of axotomized neurons following transection of peripheral and optic nerve fibers (Herdegen et al., 1990, 1991c, 1992, 1993a,b; Leah et al., 1991).

In this study we have investigated the expression of eight JUN, FOS, KROX, and CREB transcription factors in axotomized intrinsic central neurons following transection of the medial forebrain bundle (MFB) and mammillothalamic tract (MT). The expression of these transcription factors was studied in thalamic and subthalamic neurons that project ascending axons into the MFB and MT such as the substantia nigra (SN) pars compacta (SNC), nucleus (n.) mammillaris (MnM), ventral tegmental area (VTA), and n. parafascicularis of thalamus (PF) (Nieuwenhuys et al., 1982; Veening et al., 1982). In addition to transcription factors, we have studied the expression of nitric oxide synthase (NOS; EC1.14.23) by immunocytochemistry and by the NADPH-diaphorase reaction (NDP). NOS catalyzes the transformation of arginine to nitric oxide (NO) (Moncada et al., 1991). NOS and/or NO, the previously identified endotheliumderived relaxing factor, are thought to be involved in neuronglia interaction (Morris et al., 1992) and in the resistance of central neurons to ischemic and degenerative destruction (Ferrante et al., 1985; Beal et al., 1986; Koh et al., 1986; Uemura et al., 1990). Therefore, we wanted to know whether changes in NOS expression and NDP could be related to the initiation and/ or maintenance of the cell body response of axotomized neurons, and to the expression of c-JUN transcription factor following transection of MFB and MT.

\section{Materials and Methods}

Animal experiments. Adult Sprague-Dawley rats 2 months old $(250 \mathrm{gm}$ body weight) were anesthetized $(60 \mathrm{mg} / \mathrm{kg}$ pentobarbital, i.p.) and placed in a stereotaxic frame. After skin incision, a craniotomy $(2 \mathrm{~mm}$ in diameter) was performed by an electric drill on the left frontal bone (bregma -2.30 frontal and 1.50 lateral, according to Paxinos and Watson, 1989). The dura was opened and a blade $1.5 \mathrm{~mm}$ wide was introduced to $8 \mathrm{~mm}$ and immediately withdrawn by a micromanipulator. The wound was closed by Gelfoam and the overlying skin was sutured. The rats were allowed to survive for $3 \mathrm{hr}, 8 \mathrm{hr}, 12 \mathrm{hr}, 24 \mathrm{hr}$, and $36 \mathrm{hr}$ $(n=2), 3,5,10,20,30,45,60,75,100$, and $150 \mathrm{~d}(n=3)$. The identical experimental procedure was performed in 1-year-old rats that were killed after 3 and $60 \mathrm{~d}(n=3)$. In order to evaluate the effect of surgery on protein expression, the blade was introduced for $4 \mathrm{~mm}$, the dorsal border of MT; or for $6 \mathrm{~mm}$, the dorsal border of MFB. These sham controls survived each for $3 \mathrm{hr}, 24 \mathrm{hr}$, and $10 \mathrm{~d}(n=2)$. In all animals, the efficiency of operation for transection of MFB and MT was histologically investigated post-mortem and animals have been excluded when MFB and MT were only partially transected.

Immunocytochemistry. All rats were reanesthetized $(100 \mathrm{mg} / \mathrm{kg}$ pentobarbital, i.p.) and killed by transcardial perfusion ( $4 \%$ paraformaldehyde in phosphate buffer). The brains were postfixed in the same fixative and cryoprotected by $30 \%$ sucrose for $72 \mathrm{hr}$. Cryostat cut coronal sections $35 \mu \mathrm{m}$ thick were processed for immunocytochemistry as freefloating sections using the conventional avidin-biotin complex method as described in detail previously (Herdegen et al., 1991a). Immunoreactivities (IRs) were visualized by diaminobenzidine and intensified by nickel-cobalt.

All antibodies were polyclonal and generated in rabbits. They were diluted as follows: anti-c-JUN, 1:1000 (607/8) and 1:40,000 (636/3); anti-JUN B, 1:4000; anti-JUN D, 1:8000; anti-c-FOS, 1:40,000; antiFOS B, 1:2000; anti-KROX-20, 1:10,000; and anti-KROX-24, 1:8000. The two antibodies against c-JUN showed in vitro either a specific reaction with c-JUN (code 607/8) or a cross-reaction with JUN B and JUN D (code 636/3). In vivo, these antibodies gave an identical pattern of immunoreactivity, and the antibody $636 / 3$ was thus used because it

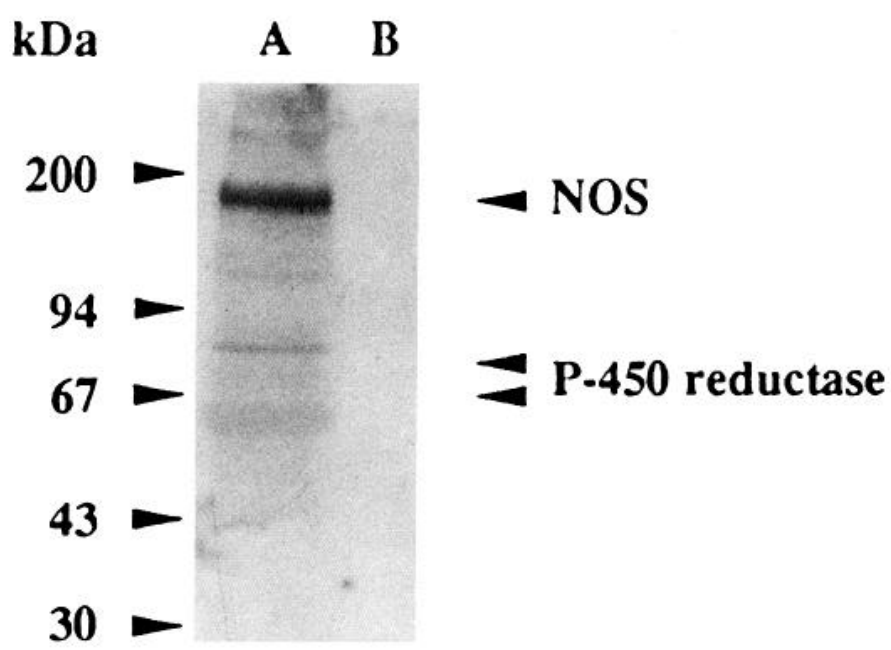

Figure 1. Immunoblotting of rat brain NOS. The anti-NOS antiserum against the N-terminal part of the NOS protein (in a dilution of 1:5000) was directed against rat brain synaptosol cytosol corresponding to about $10 \mathrm{ng}$ of NOS (NOS, lane $A$ ) and against $2 \mu \mathrm{g}$ of purified rat liver CPR450 (lane B) applied onto 10\% polyacrylamide SDS gels. The subunits of CPR-450 were localized by reversibly staining the nitrocellulose membrane with Ponceau-S.

produced less background labeling and an intense immunoreactivity (IR). The antibody against CREB (a generous gift from Dr. W. Schmid, German Cancer Research Center, Heidelberg, Germany) was diluted 1:3000. The specificity of all antibodies was demonstrated in vitro (Boshart et al., 1991; Kovary and Bravo, 1991) and in vivo by preabsorption experiments (Herdegen et al., 1991a, 1992). The monoclonal antibody against tyrosine hydroxylase (TH) (Boehringer, Mannheim, Germany) was diluted 1:4000.

To demonstrate the expression of nitric oxide synthase (NOS), two polyclonal rabbit antibodies were used. One was directed against the complete purified NOS protein (Mayer et al., 1990; Klatt et al., 1992) and was diluted 1:10,000 for immunocytochemistry. A second antibody was raised against the N-terminal peptide of NOS that does not share a homology with cytochrome $\mathrm{P}-450$ reductase (CPR-450). This antiNOS peptide antibody strongly reacted with the NOS peptide but did not cross-react at all with the CPR -450 protein (Fig. 1). Preabsorption of $1 \mathrm{nM}$ NOS peptide with the corresponding anti-NOS antibody (diluted 1:5000) for $24 \mathrm{hr}$ abolished the NOS-IR.

Activity of NOS was demonstrated by conventional NADPH-diaphorase histochemistry (NDP) using a medium containing $1 \mathrm{~mm}$ NADPH, $0.2 \mathrm{~mm}$ nitroblue tetrazolium, $0.2 \%$ Triton X-100 in 0.1 Tris$\mathrm{HCl}$ at $\mathrm{pH} 7.2$ for $30-45$ min (Scherer-Singler et al., 1983; FiallosEstrada et al., 1993). For double-labeling, either sections first underwent NDP and were subsequently processed with the anti-c-JUN antibody, or sections first underwent c-JUN staining (visualization with nickelcobalt) and were subsequently processed with the anti-NOS antibodies. All brains from every second time point were processed for anti-NOS antibodies.

Immunoblotting of rat brain NOS and purified rat liver cytochrome $P-450$ reductase. Rat brain synaptosomal cytosols with specific NOS activities of about $0.2 \mathrm{nmol} \mathrm{L}$-citrulline $\times \mathrm{mg}^{-1} \times \mathrm{min}^{-1}$ were prepared as previously described (Mayer et al., 1992). Assuming a specific activity of purified rat brain NOS of $1 \mu \mathrm{mol} \times \mathrm{mg}^{-1} \times \mathrm{min}^{-1}$ (Bredt and Snyder, 1990), these preparations contained about $0.2 \mu \mathrm{g}$ of NOS per milligram of total protein. CPR-450 purified from rat liver microsomes was a generous gift of Dr. M. Kastner (Institute of Toxicology and Embryopharmacology, University of Berlin). Rat brain synaptosomal cytosol ( $50 \mu \mathrm{m}$ of total protein corresponding to about $10 \mathrm{ng}$ of NOS) (Fig. 1, lane A) and $2 \mu \mathrm{g}$ of purified CPR-450 (Fig. 1, lane B) were diluted with sample buffer and applied onto $10 \%$ polyacrylamide SDS gel. Electrophoresis and immunoblotting were carried out as previously described (Klatt et al., 1992), and the anti-NOS antiserum against the $\mathrm{N}$-terminal part was used in a final dilution of 1:5000.

Effect of the operation on the animal behavior. Within the first postoperative week, the body weight either was not affected or was reduced by up to $15 \%$. Thereafter, the increase of body weight paralleled that 



Figure 2. c-JUN, JUN D, and KROX24 in MnM: c-JUN $(A, C, E, G)$, JUN $\mathrm{D}(B, D, F, H)$, and KROX-24 $(I, K)$ in MnM of untreated rats $(A, B, I)$, and $10 \mathrm{~d}(C, D, K), 60 \mathrm{~d}(E, F)$, and $100 \mathrm{~d}$ $(G, H)$ following transection of MFB and MT. The ventrolateral border is on the right-hand side. Scale bar, $300 \mu \mathrm{m}$.
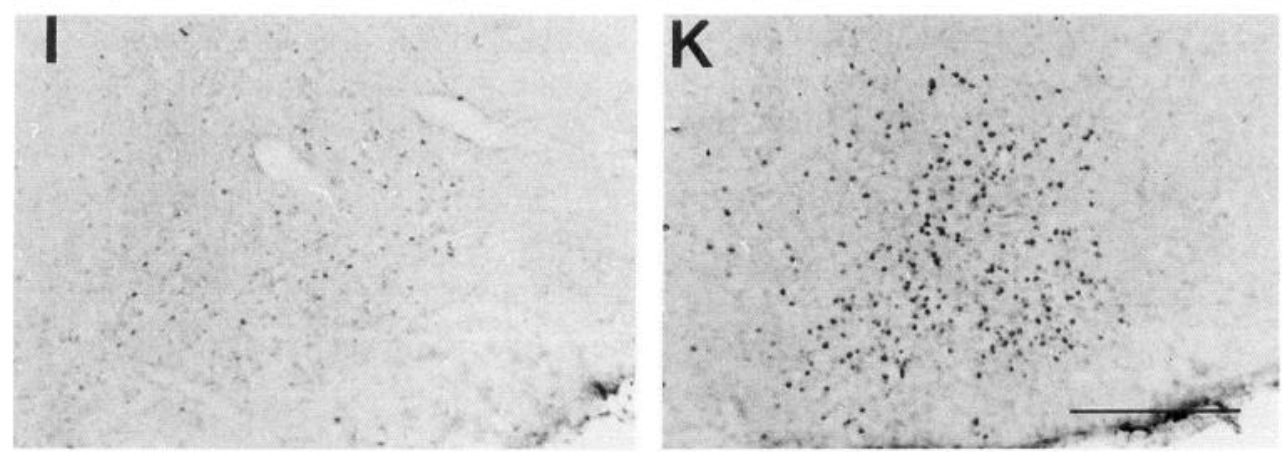

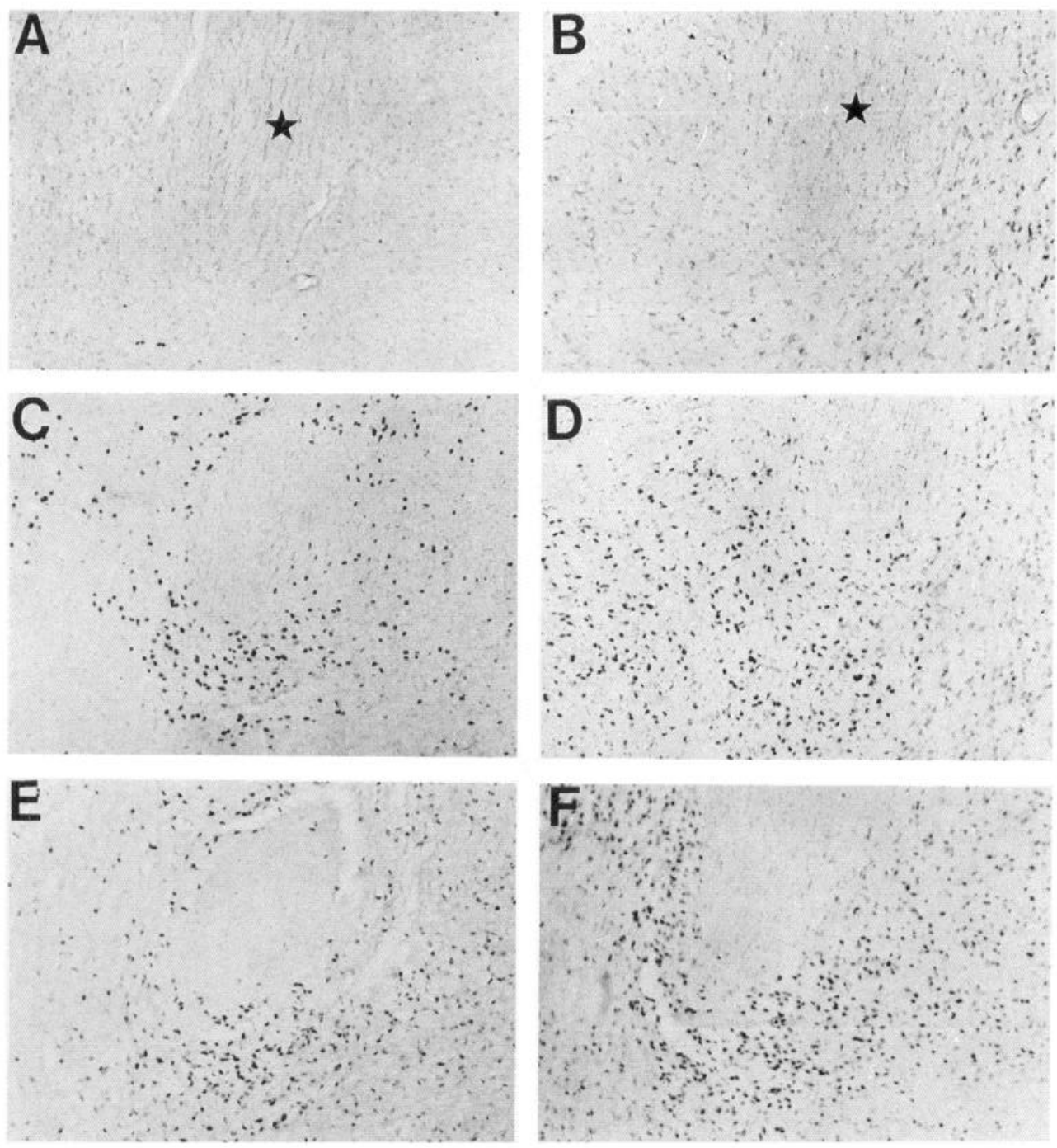

G
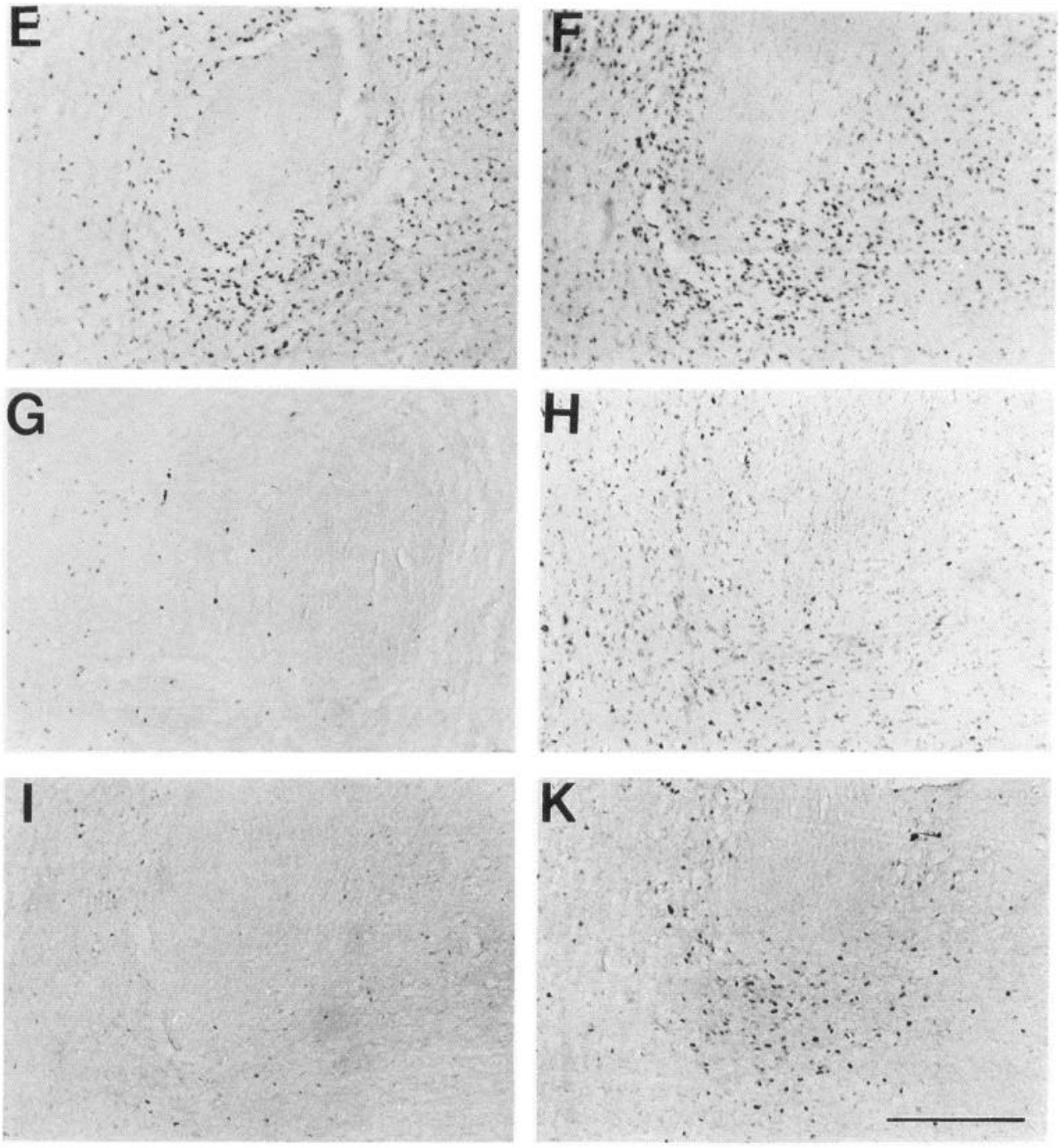

Figure 3. c-JUN, JUN D, and KROX24 in PF: c-JUN $(A, C, E, G)$, JUN D $(B, D, F, H)$, and KROX-24 $(I, K)$ in $\mathrm{PF}$ of untreated rats $(A, B, I)$, and $10 \mathrm{~d}$ $(C, D, K), 30 \mathrm{~d}(E, F)$, and $75 \mathrm{~d}(G, H)$ following transection of MFB and MT. The stars mark the fasciculus retroflexus. Dorsal is up and lateral to the right. Scale bar, $300 \mu \mathrm{m}$. 
Figure 4. c-JUN, JUN D, and KROX24 in VTA: c-JUN $(A, B)$, JUN D $(C$, $D)$, and KROX-24 $(E, F)$ in VTA of untreated rats $(A, C, E)$, and $10 \mathrm{~d}$ following transection of MFB and MT $(B$, $D, F)$. Dorsal is up and lateral is to the right. Scale bar, $150 \mu \mathrm{m}$.
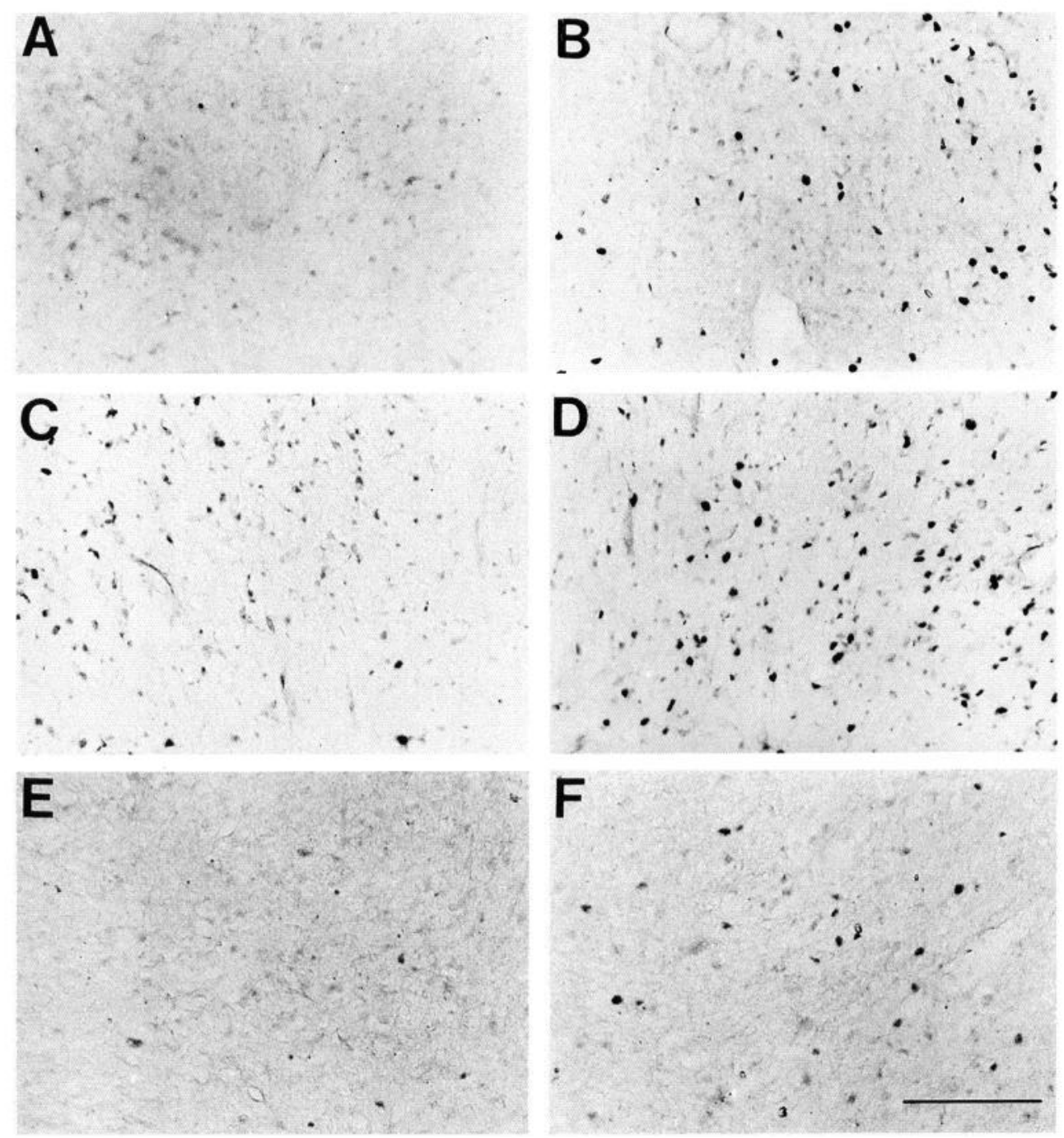

of untreated rats. Their social behavior and self-care were not affected. Six rats were excluded from the experiments and were killed within 24 $\mathrm{hr}$ following the surgery because of postsurgery stress. These rats are not included in the pool of investigated animals.

Statistics. Immunoreactive cell nuclei of MnM, PF, VTA, and SN were counted ipsilaterally to MFB and MT transection. For each area, two sections with the highest number of labeled nuclei were chosen in each rat and all counted numbers were averaged (mean \pm SD) for each time point of survival. We counted only those nuclei whose intensity of immunoreactivity was above that of the contralateral area.

\section{Results}

\section{Expression of transcription factor proteins}

$\mathrm{Ncl}$. mammillaris (MnM), ncl. parafascicularis $(P F)$, and ventral tegmental area (VTA). Thirty-six hours, but not $24 \mathrm{hr}$, after MFB and MT transection, the expression of c-JUN and JUN $\mathrm{D}$ was induced in many nuclei of the ipsilateral MnM, PF, and VTA. After $5 \mathrm{~d}$ these proteins reached their maxima in both the number of labeled nuclei and the intensity of labeling (Figs. $2 A-D, 3 A-D, 4 A-D, 5)$. For c-JUN and JUN D we counted a maximum number in $\mathrm{MnM}$ of $131 \pm 31$ and $145 \pm 28$ labeled cells per section (c/s), in PF of $103 \pm 17$ and $92 \pm 23 \mathrm{c} / \mathrm{s}$, and in VTA of $35 \pm 13$ and $46 \pm 14 \mathrm{c} / \mathrm{s}$, respectively. In MnM, the number of labeled nuclei remained at a submaximal level up to $150 \mathrm{~d}$ (Figs. $2 E-H, 5$ ). c-JUN and JUN D distinctly declined in PF after $60 \mathrm{~d}$, and were at basal levels after $100 \mathrm{~d}$ (Figs. $3 E-$ $H, 5$ ). In the VTA, the maximal expressions declined after 30 $\mathrm{d}$ and returned to basal levels after $45 \mathrm{~d}$ (Fig. 5). c-JUN and JUN D showed a close temporal and spatial pattern. The expression of KROX-24 was slightly different from that of the JUN proteins; its delayed onset occurred between $36 \mathrm{hr}$ and 3 $\mathrm{d}$, the number of labeled neurons was lower, and the IR decreased earlier (Figs. $2 I-K ; 3 I-K ; E, F ; 5$ ). The maximal numbers of KROX-24 were $88 \pm 22 \mathrm{c} / \mathrm{s}$ in MnM, $65 \pm 16 \mathrm{c} / \mathrm{s}$ in $\mathrm{PF}$, and $24 \pm 8 \mathrm{c} / \mathrm{s}$ in VTA. During the whole observation period the IRs did not change in the contralateral areas. In MnM, PF, and VTA, we could not detect IRs of JUN B, c-FOS, FOS B, and KROX-20 (Fig. 6).

Substantia nigra $(S N)$. In the $\mathrm{SN}$, two distinctly separated temporospatial patterns of JUN, FOS, and KROX-24 were observed. Within $3 \mathrm{hr}$, c-JUN, JUN B, JUN D, c-FOS, FOS B, and KROX-24 proteins became visible in the ipsilateral SN, predominantly in the medioventral area of the reticulated part (SNR) (Figs. 7 $A-D ; 8 A, C, E ; 9)$. The patterns of these early IR were similar for all proteins. Between $8 \mathrm{hr}$ and $12 \mathrm{hr}$, the maximal numbers of labeled neurons were counted for c-FOS (45 $\pm 12)$, JUN D $(42 \pm 13)$, JUN B $(39 \pm 10)$, c-JUN (36 \pm 9$)$, KROX-24 (29 \pm 12$)$, and FOS B $(21 \pm 7)$. These IRs declined between $24 \mathrm{hr}$ and $36 \mathrm{hr}$ (Figs. $8 B, D ; 9$ ), apart from JUN D, 

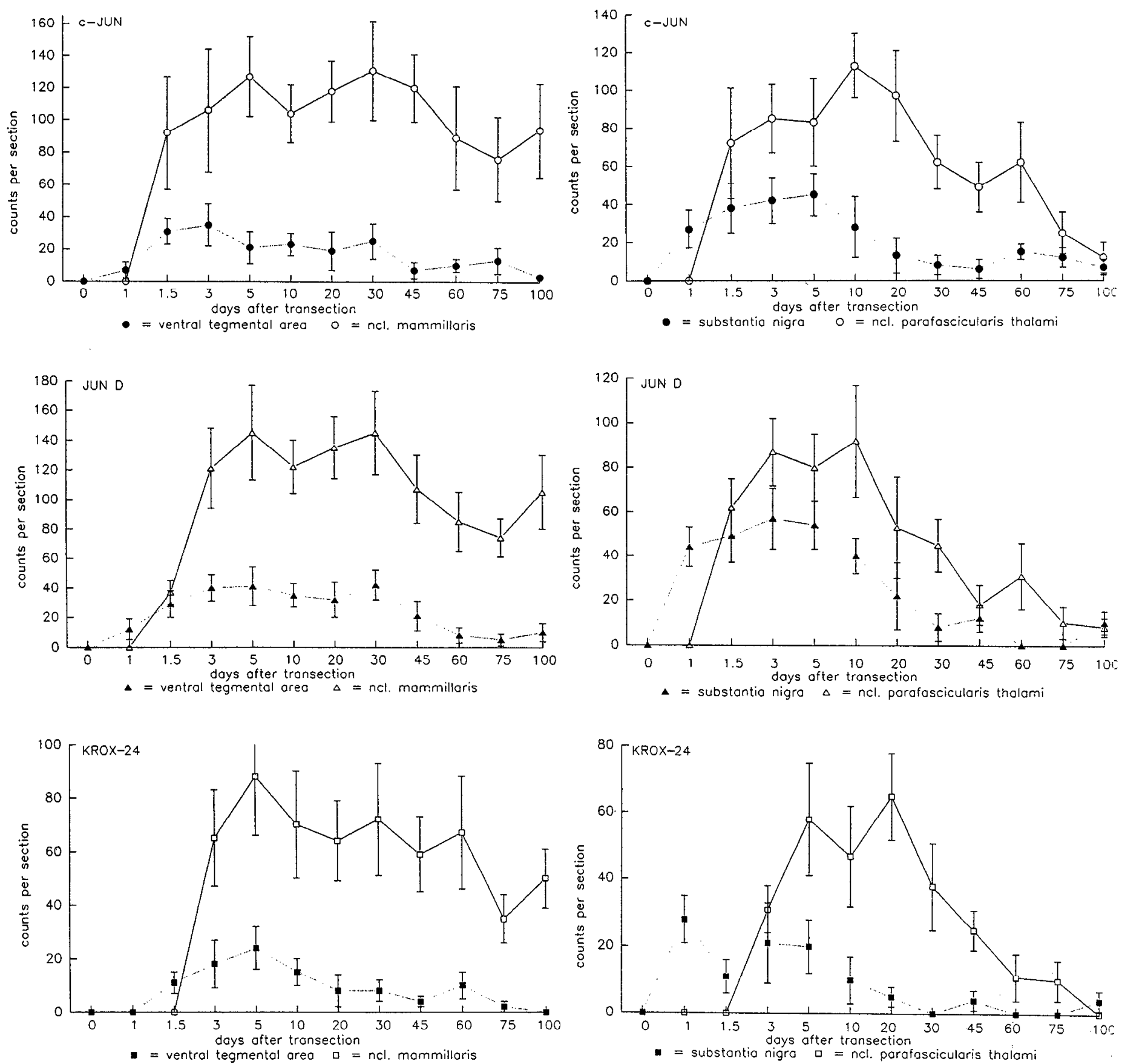

Figure 5. Time course of c-JUN, JUN D, and KROX-24 expression: the number of nuclei labeled by c-JUN, JUN D, and KROX-24 in MnM, VTA (left column), PF, and SN (right column). The counts (per $35 \mu \mathrm{m}$ section) give the number of nuclei (mean \pm SD) that show a suprabasal intensity of IR.

which persisted in the SNR for up to $10 \mathrm{~d}$ (Fig. $7 F$ ). Double labeling of c-FOS or c-JUN with TH, which marks the major population of SNC neurons, revealed that $\mathrm{TH}$ and c-FOS or c-JUN proteins are almost exclusively expressed in different neurons between $3 \mathrm{hr}$ and $36 \mathrm{hr}$ (Fig. $8 \mathrm{~A}$ ).

After $36 \mathrm{hr}$, a new pattern of immediate-early gene (IEG) expression appeared in the ipsilateral SN. c-JUN, JUN D, and KROX-24 proteins were predominantly expressed in the SNC (Figs. 7E-H, 9), and double labeling of TH with c-JUN showed a high colocalization in SNC neurons (Fig. 8E). The maximal expression of c-JUN, JUN D, and KROX-24 in the SN was visible after $5 \mathrm{~d}$. In clear contrast to $\mathrm{MnM}, \mathrm{PF}$, and VTA, however, the IRs had already declined after $10 \mathrm{~d}$ (Fig. 7G,H), and the KROX-24-IR was only weak in the SN during the entire observation period. After $30 \mathrm{~d}$, only a few labeled neurons were visible in SN. Suprabasal expression was also visible in a few neurons of the contralateral SNC that project within the ipsilateral MFB (Niewenhuys et al., 1982).

Expression of CREB. The CREB protein was constitutively expressed in apparently every neuronal and glial cell as described previously (Gonzalez et al., 1989; Herdegen et al., 1992). Because of its intense and ubiquitous expression, it was difficult 

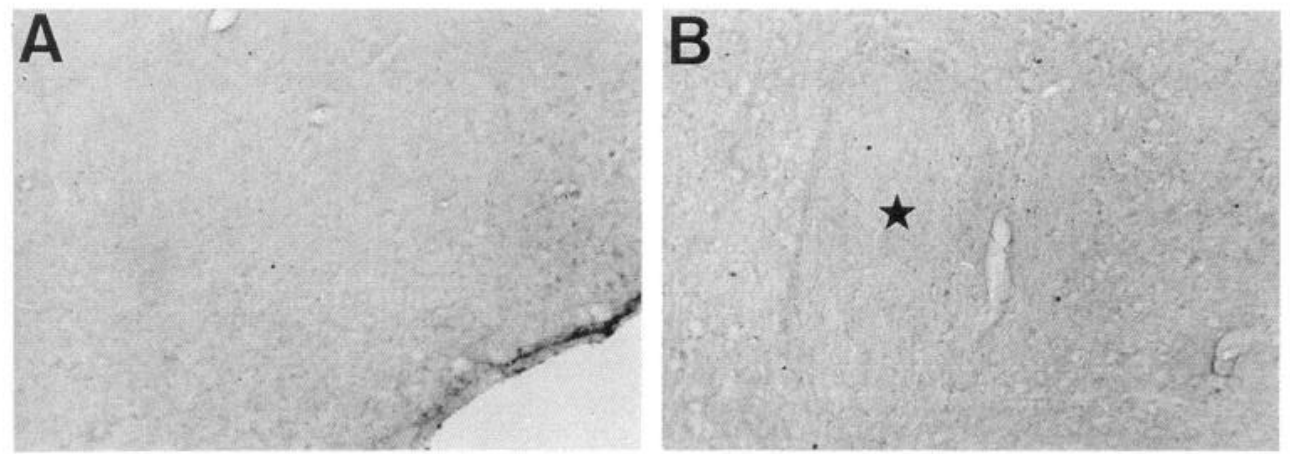

Figure 6. Absence of c-FOS, JUN B, and KROX-20 in axotomized neurons: lack of expression of $\mathrm{c}$-FOS in $\mathrm{MnM}$ $(A)$ and $\mathrm{PF}(B)$, of JUN B in MnM $(C)$, and of KROX-20 in PF $(D) 20 \mathrm{~d}$ following transection of MFB and MT. In $C$ the dashed line marks the border between SNC and SNR. In $B$ and $D$, the stars mark the fasciculus retroflexus, and in $D$ the arrow marks the basal KROX20 -IR in the dorsomedial hypothalamus. In $A-C$, dorsal is up and lateral is to the right; in $D$ dorsal is to the right and the third ventricle is on the left. Scale bars: $A-C, 300 \mu \mathrm{m} ; D, 850 \mu \mathrm{m}$.
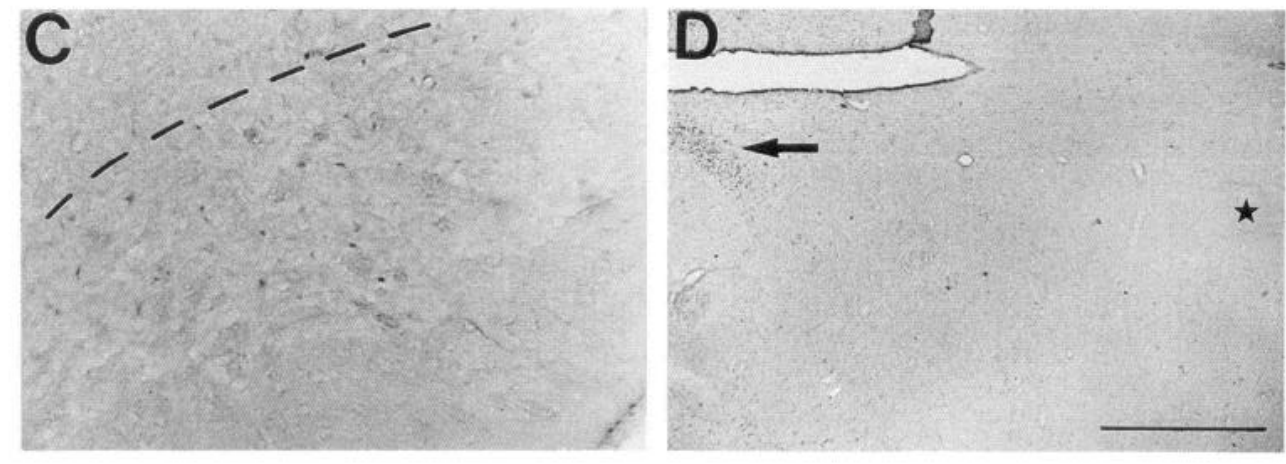

to assess significant changes in CREB-IR. In some animals we found a nonreproducible increase in labeled glial cells and a decrease of CREB-IR in neuronal nuclei ipsilateral to the transection.

\section{NADPH-diaphorase reaction (NDP) and nitric oxide synthase (NOS)-IR}

The activity of NOS was demonstrated by the NDP. The blue product of this substrate reaction showed a distribution in the cytoplasm, dendrites, axons of neurons, and blood vessels. In order to determine whether NDP was virtually related to the expression of NOS, brain sections were incubated with the antiNOS antibodies. The pattern of NDP was congruent to the patterns of NOS-IR evoked by both anti-NOS antibodies, that is, in the neocortex and the retrorubral field (Fig. 10A-D).

In the MnM of untreated rats a distinct NDP was visible only in a few neurons, and a weak NOS-IR could be discriminated from background in about 20-40 neurons per section (Fig. $12 A, C)$. In the SN and VTA, NOS-IR and NDP were present in a few neurons, but were completely absent in neurons of $\mathrm{PF}$ (Fig. 12I). The number of neurons labeled by NDP and NOSIR selectively increased in MnM neurons $10 \mathrm{~d}$ following transection of MFB and MT, reached their maxima between 20 and $30 \mathrm{~d}$ (Figs. $11 A ; 12 B, D, E ; 13 A, B$ ), and persisted at submaximal levels for up to $150 \mathrm{~d}$ (Figs. $11 B, 12 F, 13 A, B$ ). In PF, neuronal NOS-IR and NDP remained absent during the complete observation period (Fig. 12G,H). In the VTA and SN, NOS-IR and NDP, which were present in a few neurons in rats, did not change following transection of MFB and MT (Fig. 12I-K).

Interestingly, NDP was also enhanced in the neuropil around axotomized neurons, indicating an increased vascularization by capillary blood vessels (Fig. 12H). This increase of NDP was not visible in adjacent areas, thus demonstrating a local effect on vascularization following axotomy.

\section{Double labeling of NDP and NOS with c-JUN}

Sections labeled by NDP and NOS were processed for c-JUN immunocytochemistry. In MnM, 78-91\% of NDP-positive neurons also expressed c-JUN up to $150 \mathrm{~d}$ postaxotomy (Figs. $12 \mathrm{~F}$, $13 A$ ). Double labeling of NOS and c-JUN yielded colocalization values between $67 \%$ and $81 \%$ (Figs. $11 A, B ; 13 B$ ). These lower values of NOS colocalization compared to those of NDP colocalization could be explained by the finding that the small cytoplasm of many mammillary neurons gives only a weak NOS-IR that could not always be discriminated from nuclear c-JUN-IR (Fig. 11). Moreover, Figure $13 B$ includes only those NOS-positive neurons whose intensity of IR surpassed that of contralateral MnM neurons. In VTA few double-labeled neurons were seen irrespective of the time of survival.

\section{Expression patterns in 1-year-old rats}

Expression of transcription factors as well as NOS and NDP was also investigated in 1-year-old rats 3 and $60 \mathrm{~d}$ following MFB and MT transection. The patterns of all IRs and NDP did not differ from those in 3-month-old rats. Only the numbers and the intensity of KROX-24 labeled nuclei were slightly increased in ipsilateral nuclei of MnM, PF, VTA, and SNC (not shown).

\section{Control experiments}

Numerous control experiments demonstrated that the reported expression of the transcription factors was the consequence of transection of the fiber tract. The effects of surgery on JUN, FOS, and KROX expression in MnM, PF, VTA, and SN were assessed by graded introduction of the blade. Introduction down to $4 \mathrm{~mm}$, the dorsal border of MT, did not change IR; introduction down to $6 \mathrm{~mm}$, the dorsal border of MFB, transected the MT without affecting the MFB and induced c-JUN, JUN $\mathrm{D}$, and KROX-24 selectively in MnM; only the introduction 

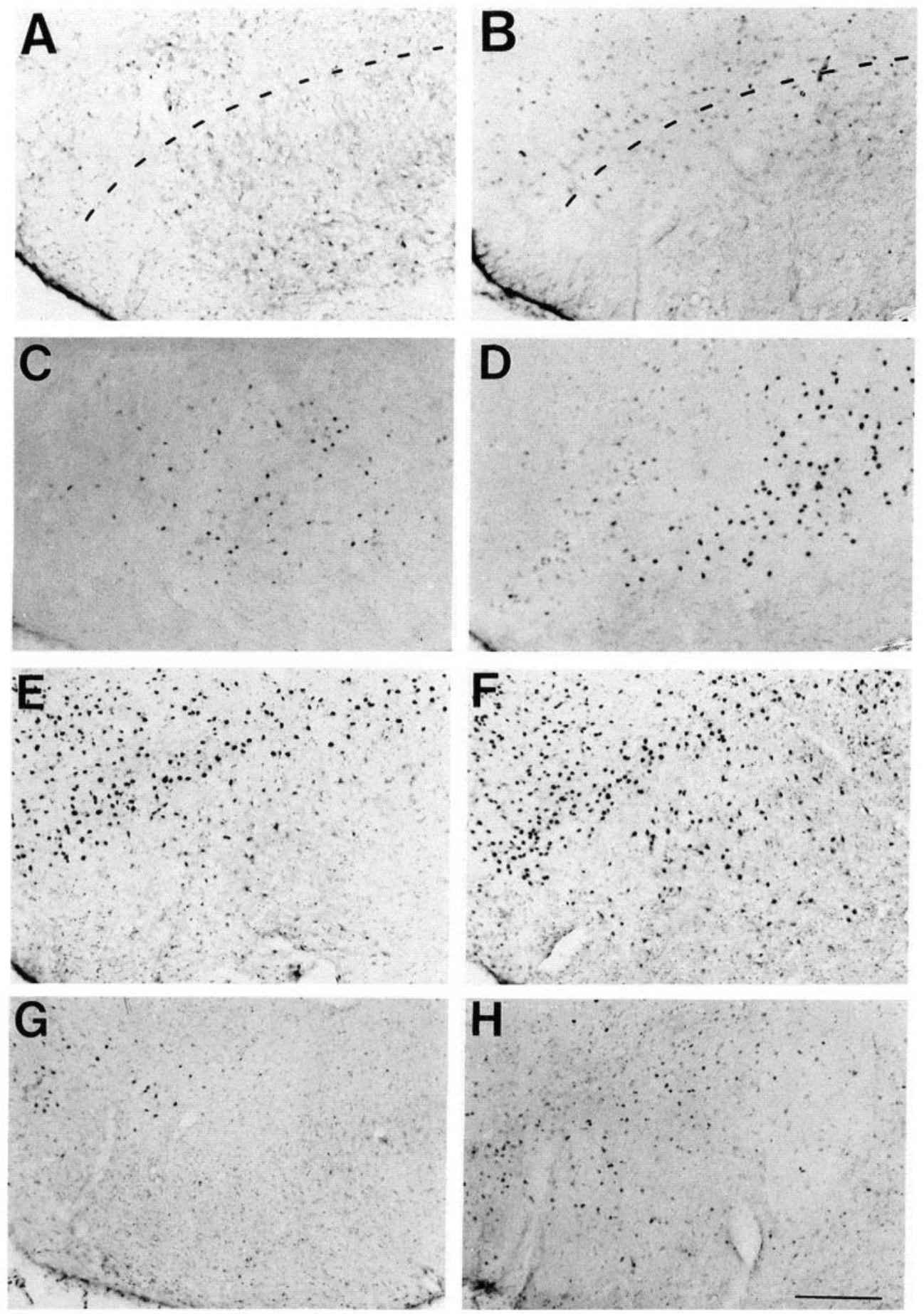

Figure 7. c-JUN, JUN D, and KROX24 in SN: c-JUN $(A, C, E)$, JUN D $(B$, $D, F)$, and KROX-24 $(G, H)$ in SN of untreated rats $(A, B, G)$, and $8 \mathrm{hr}(C$, $D)$ and $5 \mathrm{~d}(E, F, H)$ following transection of MFB and MT. The dashed lines mark the border between SNR and SNC. Scale bar, $300 \mu \mathrm{m}$. up to $9 \mathrm{~mm}$ with transection of MFB induced the described patterns of IR in PF, VTA, and SN (SNC and SNR).

\section{Discussion}

The present study describes the expression of transcription factor proteins, NOS and NDP histochemistry in axotomized intrinsic neurons of the adult rat brain. The expression of c-JUN, JUN B, JUN D, c-FOS, FOS B, KROX-20 (also termed Egr2), KROX-24 (also termed NGFI-A, Egr-1, Zif268), and CREB [also termed CRE-BP1 (Gonzalez et al., 1989; Macgregor et al., 1990)] was investigated in the MnM, PF, VTA, and the SN following transection of the MFB and MT. Our findings can be summarized as follows. (1) Axotomy of intrinsic neurons of CNS induces the expression of c-JUN, JUN D, and KROX-24, but not of JUN B, c-FOS, FOS B, or KROX-20 proteins. (2) The onset of expression started between 24 and $36 \mathrm{hr}$ after axotomy. (3) The expression of JUN and KROX-24 proteins persisted differentially in each group of axotomized neurons, ranging from $10 \mathrm{~d}$ in SN to at least $150 \mathrm{~d}$ in MnM. (4) NDP and NOS-IR were selectively increased in $\mathrm{MnM}$ where a high proportion of NDP- and NOS-labeled neurons also expressed c-JUN. The expression of NOS was demonstrated by a specific antibody 
Figure 8. c-JUN, JUN B, and c-FOS in SN. c-FOS $(A, B)$, JUN B $(C, D)$, and c-JUN $(E)$ in the SN $8 \mathrm{hr}(A, C), 36 \mathrm{hr}$ $(B, D)$, and $10 \mathrm{~d}(E)$ following transection of MFB. The dashed line marks the border between SNR and SNC. c-FOS $(A)$ and c-JUN $(E)$ are colabeled with $\mathrm{TH}$, which is only present to SNC: cFOS-IR in SNR and TH-IR in SNC are exclusive $(A)$ whereas c-JUN is mostly expressed in TH-labeled neurons. TH-IR had already strongly declined after $10 \mathrm{~d}$. Scale bar, $300 \mu \mathrm{m}$.
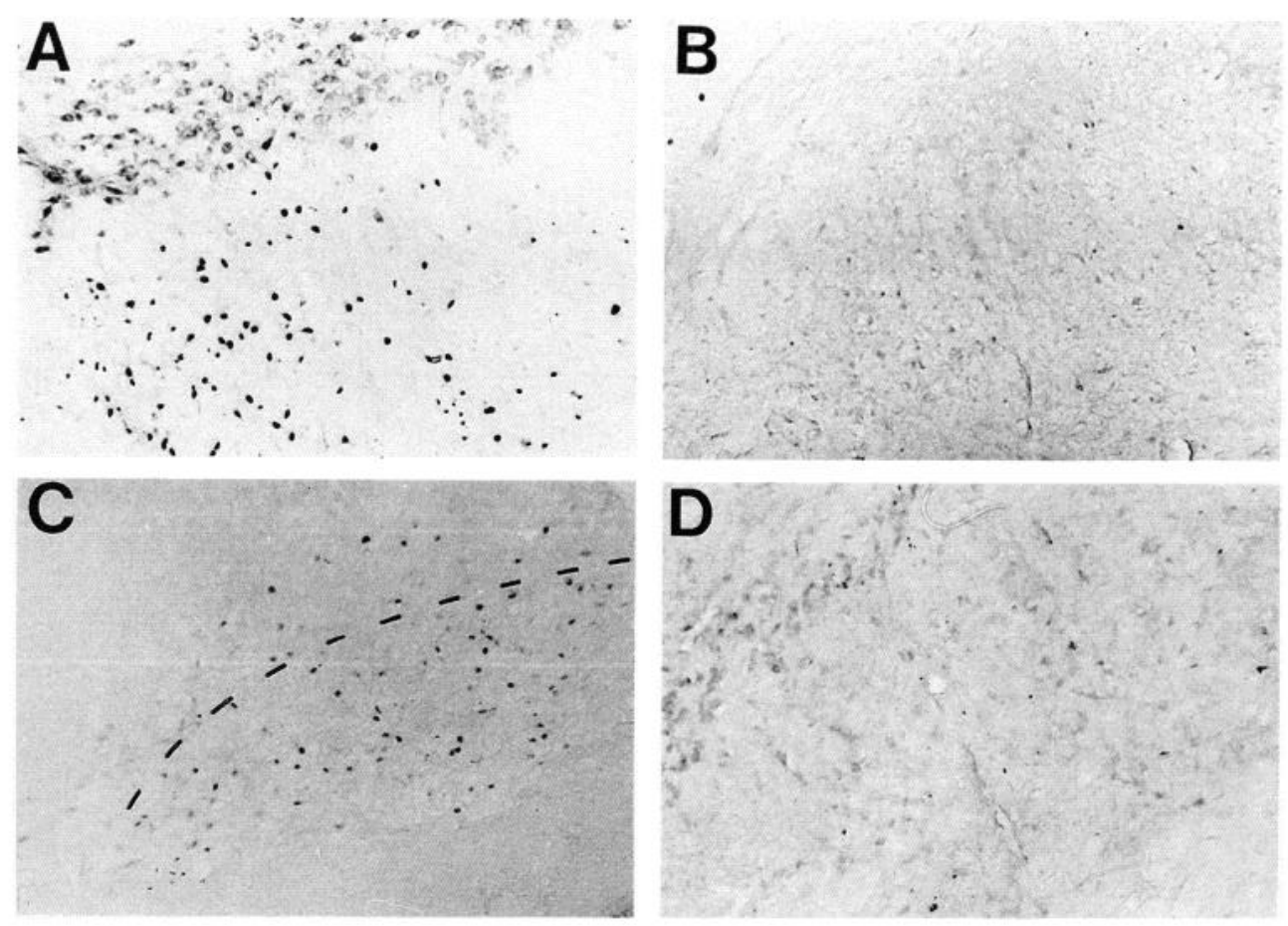

Figure 9. c-FOS and c-JUN in SN: neurons labeled by c-FOS (upper row) and c-JUN (lower row) $8 \mathrm{hr}, 24 \mathrm{hr}$, and $3 \mathrm{~d}$ following transection of MFB and MT in SNC and SNR. Each dot represents one labeled nucleus.
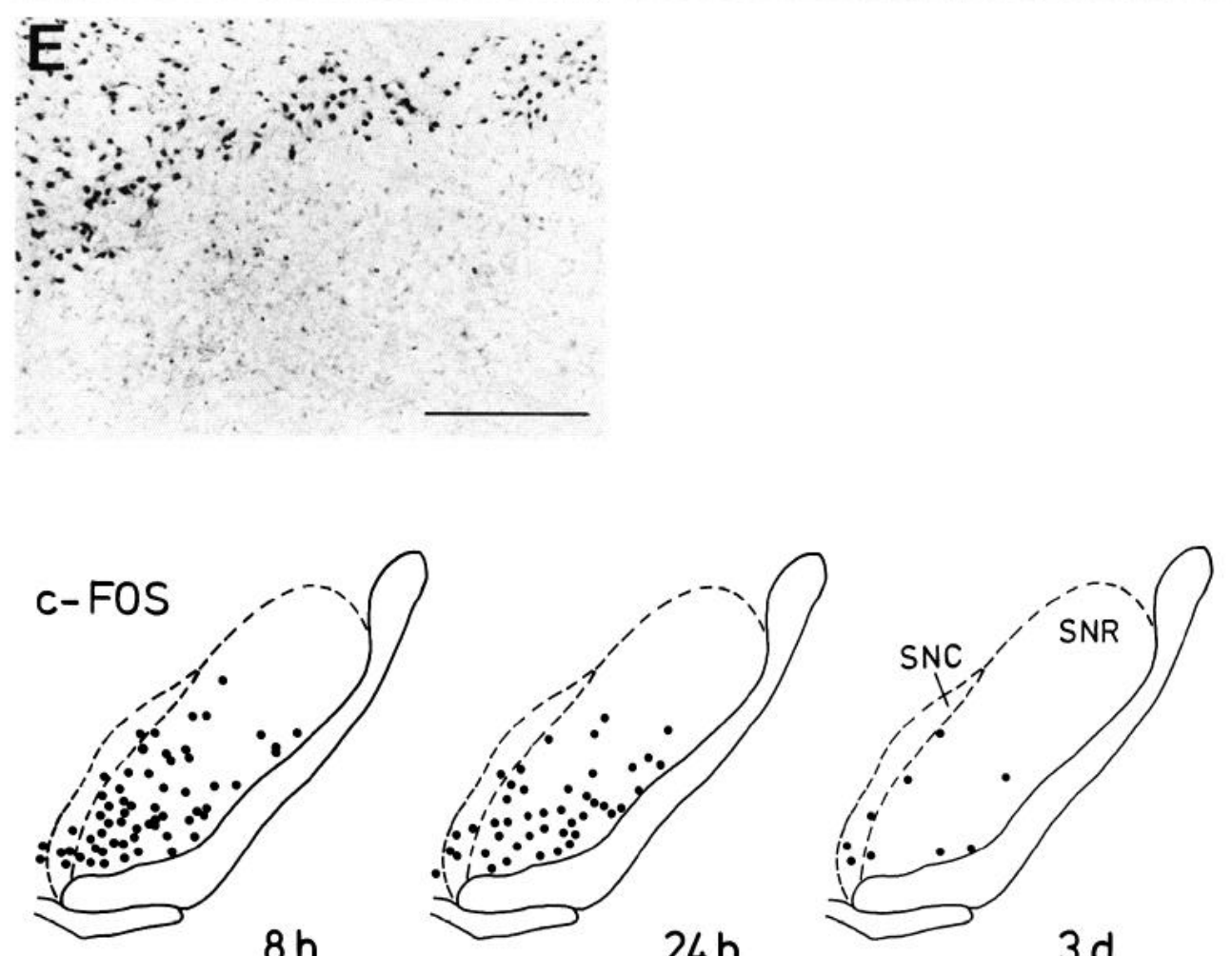

$8 \mathrm{~h}$

$24 \mathrm{~h}$
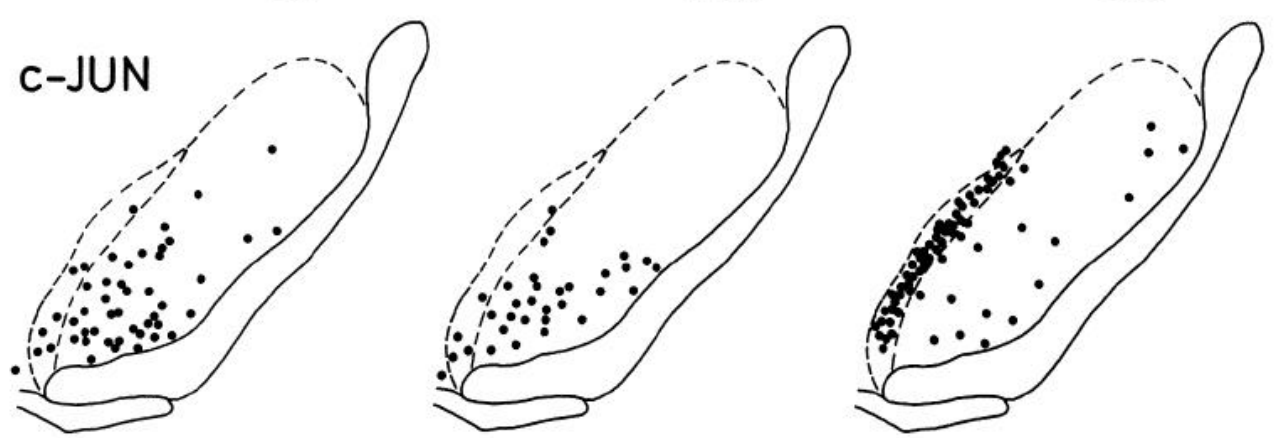

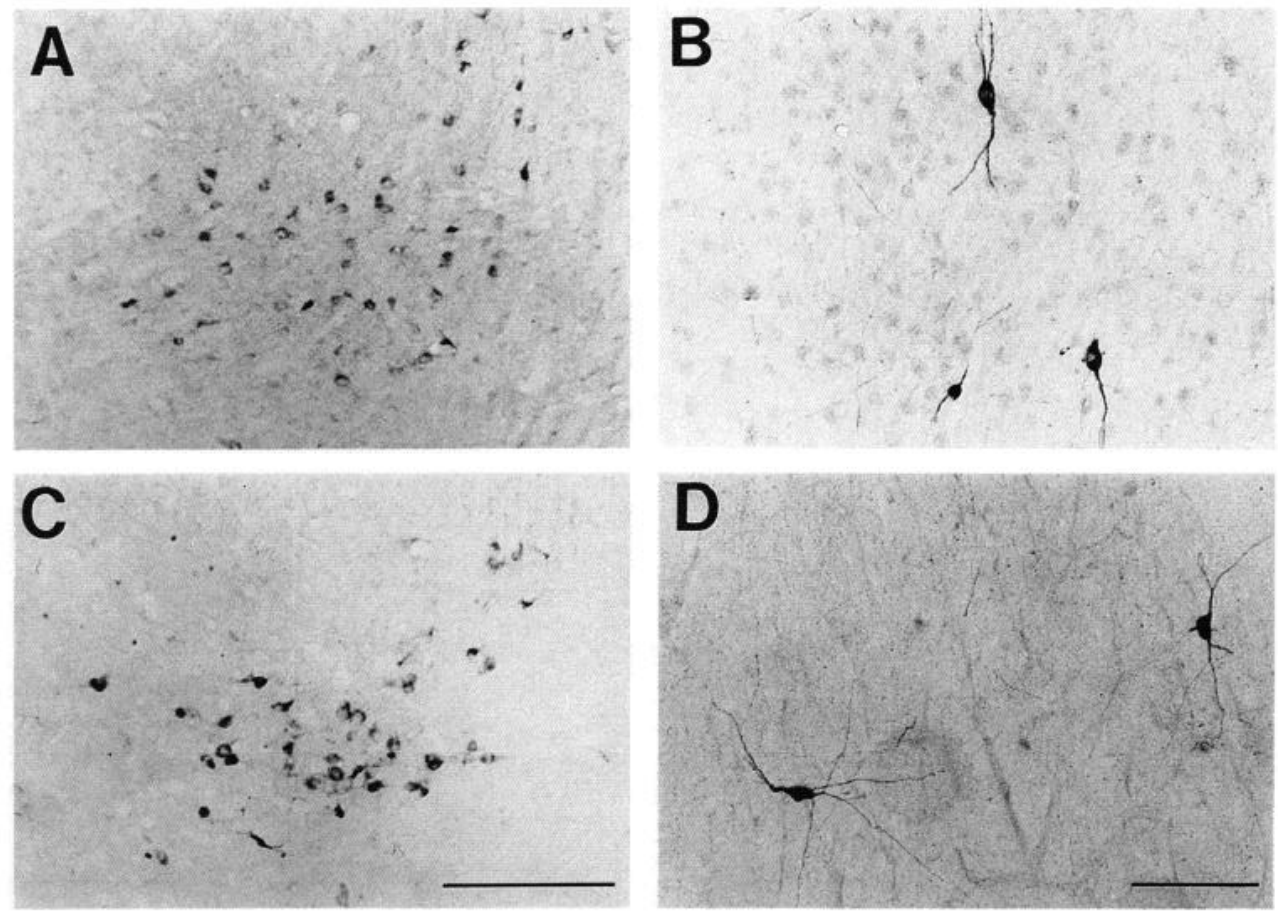

Figure 10. Comparison of NOS-IR and NDP: NOS-IR $(A, B)$ and NDP $(C$, $D$ ) in neurons of layers II-IV of parietal cortex $(A, C)$ and the retrorubral field $(B, D)$. Scale bars: $A$ and $C, 100 \mu \mathrm{m} ; B$ and $D, 50 \mu \mathrm{m}$. against the N-terminus of NOS. (5) The expression patterns of 1 -year-old rats did not differ compared to those of 3-monthold rats.

\section{Expression of JUN and $K R O X-24$ proteins is related to the transection of $M F B$ and $M T$}

The ascending and descending fiber tracts that project through the MFB and MT are well described (reviewed by Nieuwenhuys et al., 1982; Veening et al., 1982). According to these investigations, transection of the MFB and MT results in axotomy of the ipsilateral ascending projections of MnM, PF, VTA, and $\mathrm{SN}$. In sham-operated controls, IRs of all proteins did not differ from those in untreated rats. In the experimental and shamoperated groups we found an induction of all the JUN, FOS, and KROX-24 proteins but not of KROX-20 in glial and/or neuronal cells around the damaged tissue and in the ipsilateral cortical hemisphere. This pattern of expression is characteristic for mechanical local lesions of the brain and is probably propagated by local inflammatory factors and by cortical spreading depression (Dragunow et al., 1991; Gass et al., 1992a,b; Herdegen et al., 1993c).
After transection of MFB, all the JUN, FOS, and KROX-24 proteins appeared within $3 \mathrm{hr}$ in the SNR, but not in TH-labeled neurons that mark most neurons of the SNC. This is the pattern of an early and transient JUN, FOS, and KROX-24 expression resembling the well-known pattern evoked by transynaptic stimulation of neurons (Herdegen et al., 1991a, 1992, 1993c; Gass et al., 1992a). This might be due to transection of strial axons that project into the MFB to the $\mathrm{SN}$, predominantly to SNR (Fallon and Loughlin, 1985), and recently we have shown that transection of peripheral nerve fibers evokes a transient expression of JUN, FOS, and KROX-24 proteins in the deafferented spinal neurons, probably by spontaneous impulse discharge arising from transected nerve fibers (Leah et al., 1991; Herdegen et al., 1992).

In contrast, the selective expression of c-JUN, JUN D, and KROX-24 became visible in MnM, VTA, PF, and SN neurons between $24 \mathrm{hr}$ and $36 \mathrm{hr}$. The IRs were mainly restricted to the ipsilateral side and persisted between 10 and $150 \mathrm{~d}$. Apart from axotomy, transynaptic stimulation and deafferentation could also induce IEG expression. As mentioned above, transynaptic mechanisms (e.g., via neuronal circuits) should also induce JUN
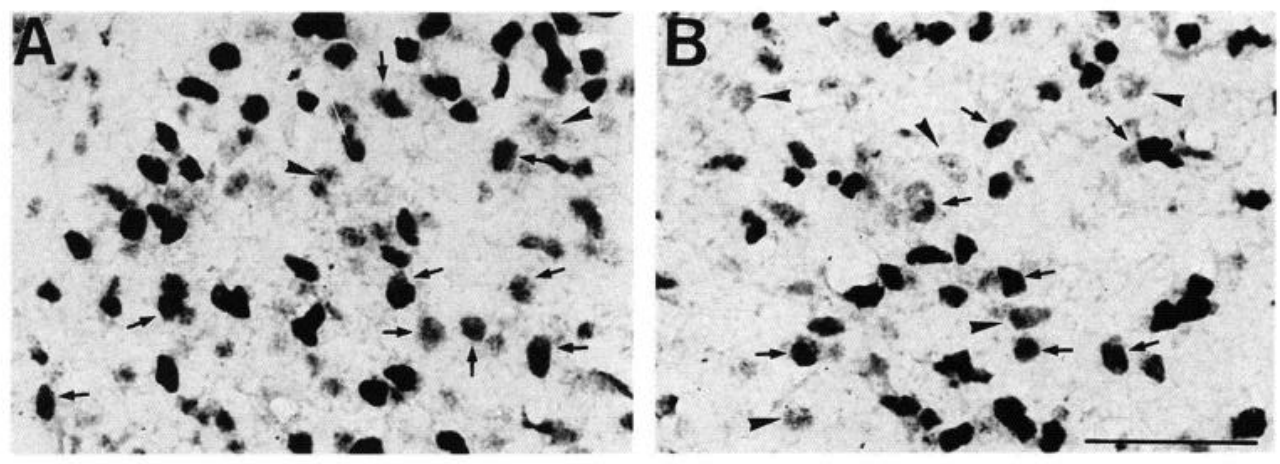

Figure 11. NOS-IR and colocalization with c-JUN in MnM neurons: cytoplasmic NOS-IR and nuclear c-JUNIR in MnM neurons $30 \mathrm{~d}(A)$ and 150 $\mathrm{d}(B)$ following transection of MT. $A r$ rows mark colocalization of c-JUN and NOS; arrowheads mark neurons labeled by NOS but not by c-JUN. Scale bar, $100 \mu \mathrm{m}$. 


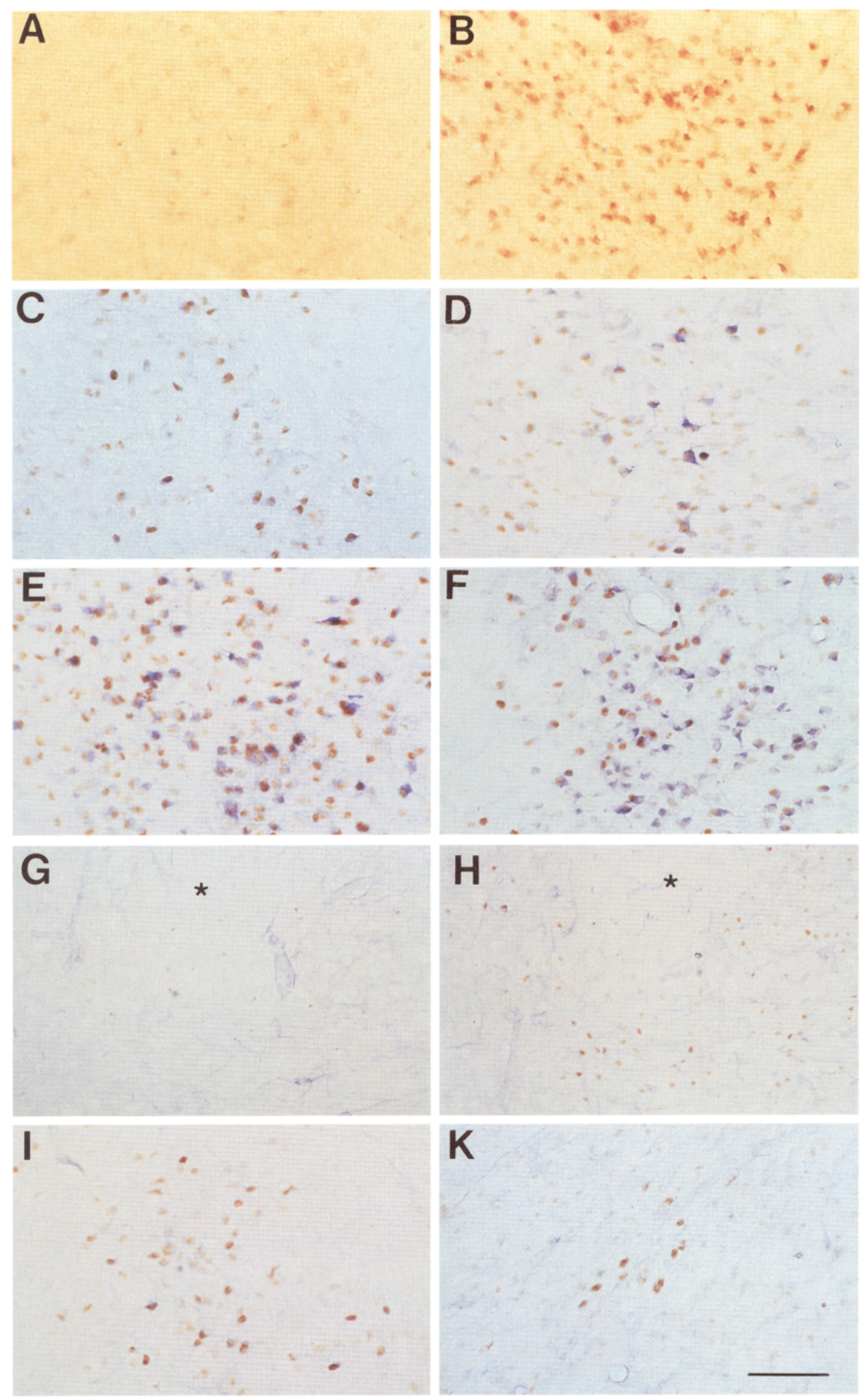

Figure 12. NOS-IR and NDP in MnM, VTA, PF, and SN: NOS-IR in MnM of untreated rats $(A)$ and $30 \mathrm{~d}$ following transection of MFB and MT $(B)$, NDP and c-JUN-IR in MnM after $3 \mathrm{~d}(C), 10 \mathrm{~d}(D), 30 \mathrm{~d}(E)$, and $150 \mathrm{~d}(F)$, and NDP and c-JUN-IR in PF of untreated rats $(G)$ and after $30 \mathrm{~d}(H)$, and in VTA $(I)$ and SN $(K)$ after $10 \mathrm{~d}$. The asterisks $(G, H)$ mark the fasciculus retroflexus. Scale bar, $150 \mu \mathrm{m}$. 
B, c-FOS, and FOS B. However, to our knowledge, transynaptic induction has never been reported to evoke a selective expression of C-JUN, JUN D, and KROX-24 proteins. Deafferentation per se of second-order neurons does not induce IEG expression in spinal neurons (Leah et al., 1991; Herdegen et al., 1992). Concordant to our data, dissociated patterns of c-Jun- and c-FosIR in SNC and SNR have been recently observed following mechanically and chemically induced axotomy of SN neurons (Jenkins et al., 1993; Weiser et al., 1993).

The signals for induction of IEGs following axotomy remain to be elucidated. Transection of MFB and MT produces a proximal axon stump of 1-3 mm length, and in spite of this short distance, the JUN and KROX expression only started between $24 \mathrm{hr}$ and $36 \mathrm{hr}$. In contrast, JUN expression is induced within $10 \mathrm{hr}$ following peripheral nerve transection in axotomized primary afferent neurons displaying a peripheral axon stump of 6$7 \mathrm{~mm}$ length (Herdegen et al., 1991 c, 1992). The comparatively late onset of axotomy-associated protein synthesis in central intrinsic neurons, which does not start before $24 \mathrm{hr}$, is a general finding (Miller et al., 1989; Mikucki and Oblinger, 1991; Tetzlaff et al., 1991), and our data indicate that this might be related to the delayed expression of transcription factors.

The selective temporospatial pattern of transcription factor expression in axotomized neurons demonstrates that, as early as at the level of transcriptional operations, cell body responses can show differential reactions due to an identical lesion. The temporal onset of c-JUN, JUN D, and KROX-24 expression is fairly similar in all axotomized neurons, whereas the decrease was differentially regulated. Thus, SN neurons express IEGencoded proteins only for up to $20 \mathrm{~d}$ whereas $\mathrm{MnM}$ neurons do so at least up to $150 \mathrm{~d}$. This difference could be related to the different potencies for neuronal survival and axonal sprouting of central neurons (Carpenter et al., 1986; Lyon and Stelzner, 1987) depending on the neuronal genotype. For instance, axotomized GABAergic rat thalamic neurons preferentially grow axons into peripheral nerve grafts whereas GABA-negative neurons fail to do so (Benfey et al., 1985). Furthermore, the regenerative potency of adrenergic neurons in vitro is stronger than that of serotonergic and dopaminergic neurons (Björklund et al., 1971, 1973; Seiger and Olson, 1977). The dopaminergic neurons of the $\mathrm{SN}$ have a particularly low potency for axonal sprouting in cell culture assays (Seiger and Olson, 1977) and their survival depend on trophic supply from striatal neurons (Burke et al., 1992). Besides SN neurons, VTA neurons also show a restricted expression of transcription factors. Interestingly, SN and VTA neurons are ontogenically derived from a common ccll complex (Seiger and Olsen, 1973). It is a relevant question whether the in vitro reduced potency might be related to the rather transient expression of transcriptionally acting proteins such as JUN and KROX-24 in axotomized neurons of SN in vivo.

The differential expression of transcriptional factors could be the result of selective neuronal responsiveness to neurotrophic factors such as NGF, brain-derived neurotrophic factor, or ciliary neurotrophic factor that support survival of central neurons such as dopaminergic neurons of $\mathrm{SN}$ in vitro (Hyman et al., 1991; Knüsel et al., 1991). The neurotrophic effects of these factors depend on the binding to their appropriate (high affinity) receptors. Recently, expression of $t r k \mathrm{~B}$ and $t r k \mathrm{C}$ mRNAs was reported in $\mathrm{MnM}$ and $\mathrm{SN}$ of untreated rats, with a particularly intense labeling of lateral MnM (Merlio et al., 1992), that area with the most sustained c-JUN and NOS expression. Upregu-
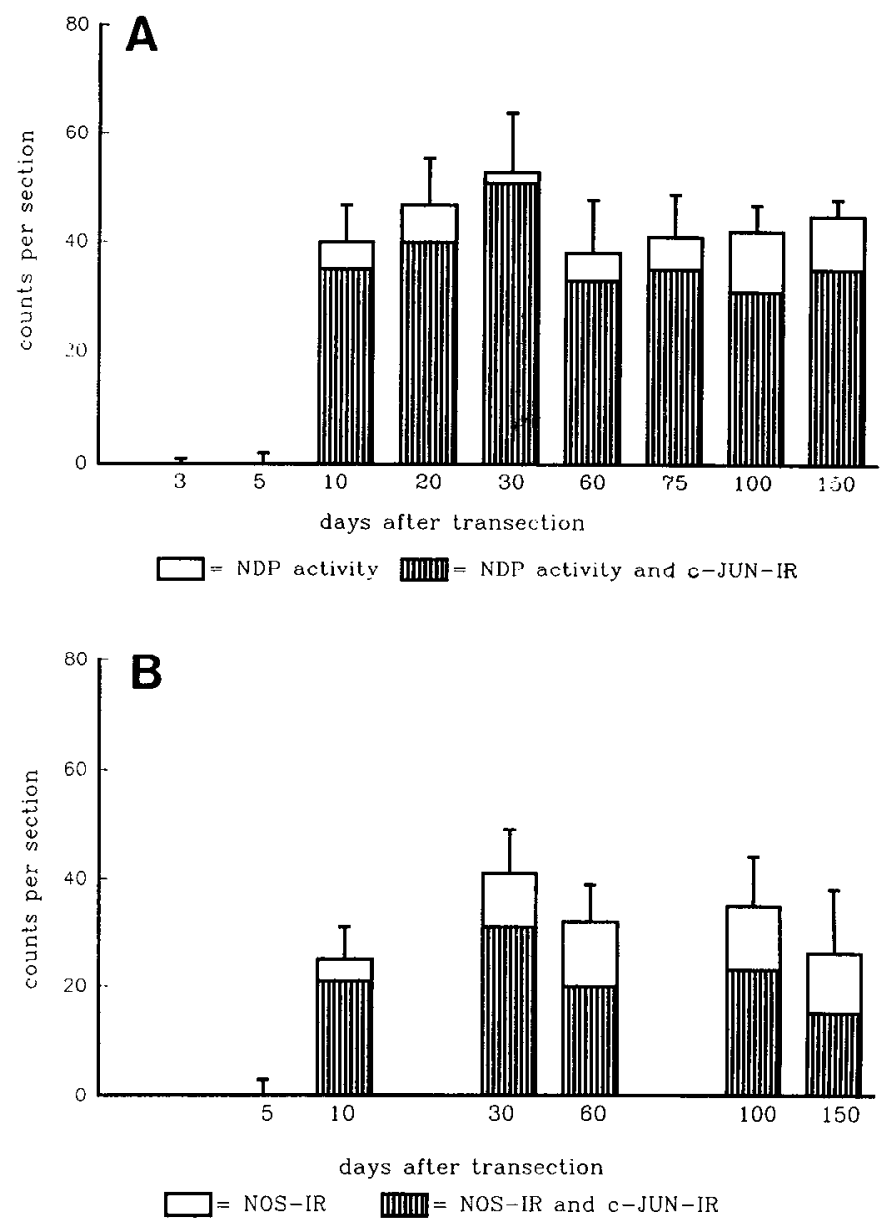

Figure 13. Time courses of NDP and NOS and their colocalization with c-JUN in MnM neurons. The bars represent the numbers (mean $\pm \mathrm{SD}$ ) of MnM neurons labeled by NDP $(A)$ and NOS $(B)$, and the hatched parts represent the number of those neurons colabeled for c-JUN. For NOS $(B)$, only every second time point was investigated.

lation of $t r k \mathrm{~B}$ mRNA was observed in injured spinal neurons (Frisen et al., 1992), and the $t r k \mathrm{~B}$ protein constitutes a receptor for the brain-derived neurotrophic factor, neurotrophin-3, and neurotrophin-4 (Klein et al., 1991, 1992).

\section{Increase of NDP and NOS-IR in the MnM}

Axotomy induces a long-lasting increase of both the NOS-IR and the NDP substrate reaction (NDP) in MnM. There is strong evidence that NDP neurons reflect the distribution of NOS in the rat brain (Bredt et al., 1991a; Dawson et al., 1991; Hope et al., 1991). The two antibodies used in the present study were directed against the entire protein or the $\mathrm{N}$-terminal part of the NOS protein (Mayer et al., 1990; Klatt et al., 1992). They displayed a congruent pattern between NOS-IR structures and NDPlabeled structures in both the CNS and PNS (Kummer et al., 1992; Fiallos-Estrada et al., 1993). Our finding of a basal NOSIR in MnM is confirmed by the previous report of a basal NOS mRNA and protein production in the rat brain (Bredt et al., 1991a). We have to take into consideration that both the NDP and the NOS-IR could have been evoked by CPR-450, which shares a close homology with NOS (Bredt et al., 1991b). However, one anti-NOS antibody did not at all cross-react with the CPR-450 protein (Fig. 1). It is also unlikely that CPR-450 contributes to our described changes of NDP and NOS-IR because 
the occurrence of CPR-450 is only restricted to a few areas in the CNS (Kapitulnik et al., 1987). Moreover, CPR-450 is differentially regulated because axotomy of $\mathrm{SN}$ neurons increases CPR-450 (Haglund et al., 1984) whereas we observed no changes of NOS-IR in axotomized SN neurons.

The close and lasting coexpression of c-JUN in NDP-labeled mammillary neurons suggests an advantageous role of NOS in the cell body response to axotomy. Several reports indicated a protective effect of the presence of NOS against ischemic, toxic, and degenerative insults in the CNS (Ferrante et al., 1985; Beal et al., 1986; Koh et al., 1986; Uemura et al., 1990). Therefore, it is an important observation that the most persisting presence of JUN and KROX-24 proteins occurs in those axotomized neurons that also show a long-lasting increase of NOS-IR and NDP. We suggest that the persistence of these transcription factors reflects a high endogenous regenerative capacity for axonal sprouting that could be supported by the action of NOS via NO (Bredt et al., 1990), for example, by lowering the intracellular levels of calcium (Garg and Hassid, 1991) or by a selfstimulation of the axotomized neurons via NO that might compensate for the axotomy-induced functional inactivation. It was also suggested that the release of NO from resistant NOS neurons could kill nearby neurons during the neurotoxicity (Bredt and Snyder, 1992). Our data indicate the viability of many neurons contacted by NDP fibers and perikarya for up to 150 $\mathrm{d}$, arguing against NO-mediated cell death following axotomy. Finally, the late increase of NOS-IR and NDP between 5 and $10 \mathrm{~d}$ excludes a major role for the cell body response but ascribe to NOS a major function during the later postaxotomy period.

The increase of NOS-IR demonstrates the inducibility of the NOS gene at least in those areas with basal NOS expression. Very similar, NOS mRNA and protein increased following axotomy in primary afferent neurons that displayed basal NOS expression, and these axotomized neurons also showed a high colocalization of NOS and c-JUN (Verge et al., 1992; FiallosEstrada et al., 1993). Thus, axotomy presents an adequate stimulus for de novo expression of NOS in the rodent PNS and CNS.

\section{Meaning of C-JUN, JUN D, and KROX-24 expression}

It is a striking phenomenon that an intense and long-lasting expression of c-JUN and JUN D is not at all paralleled by expression of c-FOS and FOS B proteins. It was demonstrated that an increase of c-jun mRNA in axotomized neurons underlies the enhanced JUN-IR (Jenkins and Hunt, 1991; Rutherfurd et al., 1992; Hass et al., 1993; Jenkins et al., 1993). The mechanism of signal transduction is not known that induces JUN without FOS proteins; its investigation might also offer a novel key for uncovering the (selective) second messenger systems operating for the onset and maintenance of the cell body response.

It was generally accepted that JUN and FOS proteins have to form heterodimers for effective transcriptional control (reviewed by Curran and Franza, 1988). However, several reports have already described a dissociation of c-jun and c-fos expression in vitro (Bartel et al., 1989; Zwiller et al., 1991; Trejo et al., 1992). Axotomy presents the first in vivo pathophysiological condition for such a selective expression pattern. This dissociation was alrcady visible by the basal constitutive expression of c-JUN and JUN D in the CNS in the absence of any c-FOS expression (Herdegen et al., 1991b, 1993c; Mellström et al., 1991).
Our data also demonstrate the dissociation of KROX-24 and c-FOS expression following axotomy. In contrast, previously the induction of krox-20 and krox-24 mRNA has been reported to be closely linked to that of c-fos mRNA in vitro and in vivo (Chavrier et al., 1988, 1989; Christy et al., 1988; Lemaire et al., 1988; Sukhatme et al., 1988; Gass et al., 1992a). Moreover, transynaptic stimulation of central neurons, for example, by noxious somatosensory stimulation, cortical spreading depression, and epileptic seizures, induces FOS, JUN, and KROX-24 proteins in a characteristic temporospatial order in CNS neurons. In these cases the numbers of KROX-24- and c-FOSlabeled neurons exceed those labeled by c-JUN and JUN D (Herdegen et al., 1991a, 1993c; Gass et al., 1992a,b).

The absence of FOS proteins following axotomy (Sharp et al., 1989; Leah et al., 1991; Herdegen et al., 1992) raises the question about effective transcriptional operations of JUN proteins. Apart from FOS proteins, c-JUN is able to form in vitro transcriptional complexes with CREB/ATF proteins (Benbrook and Jones, 1990; Macgregor et al., 1990), helix-loop-helix protein MyoD (Bcngal et al., 1992), and liver regeneration factor-1 (Hsu et al., 1992). c-JUN can bind to various classes of DNA consensus sequences such as CRE and AP-1 (Sassone-Corsi et al., 1990; Ryseck and Bravo, 1991), and moreover, JUN proteins have the capability for a dynamic composition of transcription complexes (Ryseck and Bravo, 1991; Sonnenberg et al., 1989a). This functional variability predetermines transcription factors such as c-JUN for transcription control of effector genes during the regeneration process. Axotomy evokes complex changes of induction and suppression of genes, and by formation of variable complexes with changing partners, $c$-JUN could be involved in the intricate transcription control in damaged neurons.

The present and recent data demonstrate that the expression of C-JUN and JUN D is a constituent of the cell body response following complete axotomy of peripheral and central neurons in the rat (Herdegen et al., 1990, 1991c, 1992, 1993a,b; Jenkins and Hunt, 1991; Leah et al., 1991; Dragunow, 1992; FiallosEstrada et al., 1993; Jenkins et al., 1993). Moreover, appearance of JUN-IR in axotomized retinal ganglion cells of the goldfish indicates a conserved reaction during evolution (Herdegen et al., 1993a).

KROX-20 and JUN B were not induced by axotomy but both genes are expressed in the brain during development (Wilkinson et al., 1989a,b). These findings show that even at the transcriptional level the cell body response cannot be simply considered as replication of developmental processes. The absence of JUN $B$ in axotomized neurons deserves particular interest for two reasons: first, conflicting data contribute to JUN B a function in both the growth arrest, that is, in myeloid cells (Lord et al., 1990), and the promotion of sprouting, that is, in primary hippocampal neurons (Schlingensiepen et al., 1992). JUN B represses the activation of promoters mediated by $\mathrm{c}-\mathrm{JUN}$ and c-FOS (Schütte et al., 1989; Hsu et al., 1992; Deng and Karin, 1993), counteracting the transcriptional upregulation of target genes of c-JUN. Thus, the absence of JUN B could contribute to the long-lasting expression of c-JUN because c-JUN upregulates its own transcription. Second, the absence of JUN B protein suggests a block of its mRNA translation. The induction of jun $B$ mRNA was found in axotomized facial motoneurons (Haas et al., 1993), whereas nuclear JUN B-IR could not be detected (C. A. Haas and T. Herdegen, unpublished observations). Our data clearly demonstrate that $\mathrm{SN}$ neurons can present 
a distinct JUN B-IR following transynaptic stimulation (Fig. $8 C$ ) but not following axotomy.

Functions of JUN and FOS proteins have also to be discussed in regard to their modulation of further transcription factors. JUN and FOS proteins positively and negatively interact the DNA binding of steroid hormone receptors and of vitamin A and D derivatives, and vice versa (Schüle et al., 1990; Shemshedini et al., 1991; Touray et al., 1991; Zhang et al., 1991). Because regenerative efforts of axotomized neurons are also under the control of steroid hormones (Scheff et al., 1980; Yu and $\mathrm{Yu}, 1983$; Gorski, 1985), these humoral factors could contribute to the differential expression patterns and variable functions of AP-1 proteins in the cell body response.

The IEG encoded c-JUN, JUN D, and KROX-24 proteins are nuclear transcription factors (Milbrandt, 1987; Almendral et al., 1988; Ryseck et al., 1988; Hirai et al., 1989; Bravo, 1990). What could be their target genes in axotomized central neurons? At present, the NFG, prodynorphin, and proenkephalin genes have been described as target genes of JUN and FOS proteins (Sonnenberg et al., 1989b; Hengerer et al., 1990; Naranjo et al., 1991). There is evidence that intrinsic central neurons can respond to axotomy with a long-lasting expression of regenerationassociated effector genes, for example, with expression of GAP43 mRNA and T- $\alpha$-1-tubulin mRNA up to $50 \mathrm{~d}$ (Kalil and Skene, 1986; Skene, 1989; Mikucki and Oblinger, 1991; Tetzlaff ct al., 1991). The prolonged increase of JUN and KROX-24 proteins could be the transcriptional prerequisite for persisting expression of such genes. Our results suggest that the fate of damaged central neurons depends on their molecular genetic organization and capacity to control gene expression, in addition to the already documented inhibitory effects of the extracellular matrix (Schnell and Schwab, 1990; David et al., 1991). The present findings of differential transcriptional operations and their putative meaning for the potency of axonal sprouting could be relevant for new strategies to improve the recovery of central nerve fibers after injury.

\section{References}

Almendral JM, Sommer D, MacDonald-Bravo H, Burckhard J, Perera J, Bravo R (1988) Complexity of the early genetic response to growth factors in mouse fibroblasts. Mol Cell Biol 8:2140-2148.

Bartel DP, Sheng M, Lau LF, Greenberg ME (1989) Growth factors and membrane depolarization activate district programs of early response gene expression: dissociation of fos and jun induction. Genes Dev 3:304-313.

Bastmeyer M, Beckmann M, Schwab M, Stuermer C (1991) Growth of regenerating gold fish axons is inhibited by rat oligodendrocytes and CNS myelin but not by goldfish optic nerve tract oligodendrocyte like cells and fish CNS myelin. J Neurosci 11:626-640.

Beal MF, Kowall NW, Ellison DW, Mazurek MF, Swartz KJ, Martin JB (1986) Replication of the neurochemical characteristics of Huntington's disease by quinolinic acid. Nature 321:168-171.

Benbrook DM, Jones NC (1990) Heterodimer formation between CREB and JUN proteins. Oncogene 5:295-302.

Benfey M, Bünger UR, Vidal-Sanz M, Bray GM (1985) Axonal regeneration from GABAergic neurons in the adult rat thalamus. $J$ Neurocytol 14:279-296.

Bengal E, Ransone L, Scharfmann R, Dwarki VJ, Tapscott SJ, Weintraub H, Verma I (1992) Functional antagonism between c-Jun and MyoD proteins: a direct physical association. Cell 68:507-519.

Björklund A, Katzman R, Stenevi IJ, West KA (1971) Development and growth of axonal sprouts from noradrenaline and 5-hydroxytryptamine neurones in the rat spinal cord. Brain Res 31: 21-33.

Björklund A, Nobin A, Stenevi U (1973) Regeneration of central serotonin neurons after axonal degeneration induced by 5,6-dihydroxytryptamine. Brain Res 50:214-220.

Boshart M, Weih F, Nichols M, Schütz G (1991) The tissue-specific extinguisher locus TSEI encodes a regulatory subunit of cAMP-dependent protein kinase. Cell 66:849-859.

Bravo R (1990) Growth factor inducible genes in fibroblasts. In: Growth factors, differentiation factors and cytokines (Herschman A, ed), pp 324-343. Berlin: Springer.

Bredt DS, Snyder SH (1990) Isolation of nitric oxide synthetase, a calmodulin-requiring enzyme. Proc Natl Acad Sci USA 87:682-685.

Bredt DS, Snyder SH (1992) Nitric oxide, a novel neuronal messenger. Neuron 8:3-11.

Bredt DS, Hwang PM, Snyder SH (1990) Localization of nitric oxide synthase indicating a role for nitric oxide. Nature 347:768-770.

Bredt DS, Glatt CE, Hwang PM, Fotuhi M, Dawson TM, Snyder SH (1991a) Nitric oxide synthase protein and mRNA are discretely localised in neuronal populations of the mammalian CNS together with NADPH diaphorase. Neuron 7:615-624.

Bredt DS, Hwang PM, Glatt CE, Lowenstein C, Reed RR, Snyder SH (1991b) Cloned and expressed nitric oxide synthase structurally resembles cytochrome P-450 reductase. Nature 351:714-718.

Burke RE, Macaya A, DeVivo D, Kenyon N, Janec EM (1992) Neonatal hypoxic-ischemic or excitotoxic striatal injury results in a decreased adult number of substantia nigra neurons. Neuroscience 50: $559-569$.

Carpenter P, Sefton J, Dreher B, Lim WL (1986) Role of target tissue in regulating the development of retinal ganglion cells in the albino rat: effects of kainate lesions in the superior colliculus. J Comp Neurol 251:240-259.

Chavrier P, Zerial M, Lemaire P, Almendral J, Bravo R, Charnay $\mathbf{P}$ (1988) A gene encoding a protein with zinc fingers is activated during $\mathrm{G} 0 / \mathrm{G} 1$ transition in cultured cells. EMBO J 7:29-35.

Chavrier P, Janssen-Timmen U, Mattei MG, Zerial M, Bravo R, Charnay $P$ (1989) Structure, chromosome location, and expression of the mouse zinc finger gene krox-20: multiple gene products and coregulation with the proto-oncogene c-fos. Mol Cell Biol 9:787-797.

Christy BA, Lau LF, Nathans D (1988) A gene activated in mouse $3 \mathrm{~T} 3$ cells by serum growth factors encodes a protein with "zinc finger" sequences. Proc Natl Acad Sci USA 85:7857-7861.

Curran T, Franza BR Jr (1988) Fos and Jun: the AP-1 connection. Cell 55:395-397.

David S, Aguayo A (1981) Axonal elongation into peripheral nervous system "bridges" after central nervous system injury in adult rats. Science 214:931-933.

David S, Bouchard C, Tsatas O, Giftochristos N (1991) Macrophages can modify the non-permissive nature of the adult mammalian central nervous system. Neuron 5:463-469.

Davies AM (1989) Intrinsic differences in the growth rate of early nerve fibres related to target distance. Nature 337:553-555.

Dawson TM, Bredt DS, Fotuhi M, Hwang PM, Snyder SM (1991) Nitric oxide synthase and neuronal NADPH diaphorase are identical in brain and peripheral tissues. Proc Natl Acad Sci USA 88:77977801 .

Deng T, Karin M (1993) JunB differs from c-Jun in its DNA-binding and dimerization domains, and represses $\mathrm{c}-J u n$ by formation of inactive heterodimers. Genes Dev 7:479-490.

Dragunow M (1992) Axotomized medial septal-diagonal band neurons express Jun-like immunoreactivity. Mol Brain Res 15:141-144.

Dragunow M, de Castro D, Faull RLM (1991) Induction of Fos in glia-like cells after focal brain injury but not during Wallerian degeneration. Brain Res 527:41-54.

Fallon JH, Loughlin SE (1985) Substantia nigra. In: The rat nervous system (Paxinos G, ed), pp 353-374. New York: Academic.

Fawcett JW (1992) Intrinsic neuronal determinants of regeneration. Trends Neurosci 15:5-8.

Ferrante RJ, Kowall NW, Beal MF, Richardson EP, Bird ED, Martin JB (1985) Selective sparing of a class of striatal neurons in Huntington's disease. Science 230:561-563.

Fiallos-Estrada CE, Herdegen T, Kummer W, Mayer B, Bravo R, Zimmermann $M$ (1993) Long-lasting increase of nitric oxide synthase immunoreactivity, NADPH-diaphorase reaction and c-JUN co-expression in rat dorsal root ganglion neurons following sciatic nerve transection. Neurosci Lett 150:169-173.

Frisen J, Verge VMK, Cullheim S, Persson H, Fried K, Middlemas DS, 
Hunter T, Hökfelt, Risling M (1992) Incrcascd lcvels of trkB mRNA and trkB protein-like immunoreactivity in the injured rat and cat spinal cord. Proc Natl Acad Sci USA 89:11282-11286.

Garg UC, Hassid A (1991) Nitric oxide decreases cytosolic free calcium in BALB/c3T3 fibroblasts by cyclic GMP-independent mechanisms. J Biol Chem 266:9-12.

Gass P, Herdegen T, Kiessling M, Bravo R (1992a) Induction of immediate early gene encoded proteins in the rat hippocampus after bicuculline-induced seizures: differential expression of KROX-24, FOS and JUN proteins. Neuroscience 48:314-323.

Gass P, Spranger M, Herdegen T, Bravo R, Hacke W, Kiessling M (1992b) Expression of FOS and JUN proteins following focal ischemia in the rat cortex: differential effects of NMDA antagonist treatment. Acta Neuropathol (Berl) 84:545-553.

Gonzalez GA, Yamamoto KY, Fischer WH, Karr D, Menzel P, Biggs W III, Vale WW, Montminy MR (1989) A cluster of phosphorylation sites on the cyclic AMP-regulated nuclear factor CREB predicted by its sequence. Nature 337:749-752.

Gorski RA (1985) Gonadal hormones as putative neurotrophic substances. In: Synaptic plasticity (Cotman CW, ed), pp 287-310. New York: Guilford.

Haas CA, Donath C, Kreutzberg GW (1993) Differential expression of immediate early genes after transection of the facial nerve. Neuroscience 53:91-99.

Haglund L, Köhler C, Haaparanta T, Goldstein M, Gustafsson JA (1984) Presence of NADPH-cytochrome P450 reductase in central catecholaminergic neurones. Nature 307:259-262.

Hengerer B, Lindholm R, Heumann R, Rüther U, Wagner EF, Thoenen H (1990) Lesion-induced increase in nerve growth factor mRNA is mediated by c-fos. Proc Natl Acad Natl USA 87:3899-3903.

Herdegen T, Leah JD, Bravo R (1990) Different expression of JUN, FOS and KROX-24 proteins in adult CNS: dependence on neurobiological events. J Cell Biochem 14F:310.

Herdegen T, Kovary K, Leah J, Bravo R (1991a) Specific temporal and spatial distribution of JUN, FOS and KROX-24 proteins in spinal neurons following noxious transynaptic stimulation. J Comp Neurol 313:178-191.

Herdegen T, Leah J, Manisali A, Bravo R, Zimmermann M (1991b) c-JUN-like immunoreactivity in the CNS of the adult rat: basal and transynaptically induced expression of an immediate-early gene. Neuroscience 41:643-654.

Herdegen T, Kummer W, Fiallos CE, Leah J, Bravo R (1991c) Expression of c-JUN, JUN B and JUN D in the rat ncrvous system following transection of vagus nerve and cervical sympathetic trunk. Neuroscience 45:413-422.

Herdegen T, Fiallos-Estrada CE, Schmid W, Bravo R, Zimmermann $M$ (1992) The transcription factors c-JUN, JUN D and CREB proteins, but not FOS and KROX-24, are differentially regulated in axotomized neurons following transection of rat sciatic nerve. Mol Brain Res 14:155-165.

Herdegen T, Bastmeyer M, Bähr M, Bravo R, Stürmer CAO, Zimmermann M (1993a) Expression of JUN, KROX and CREB transcription factors in goldfish and rat retinal ganglion cells following optic nerve lesion is related to axonal sprouting. J Neurobiol 24:528543.

Herdegen T, Fiallos-Estrada CE, Bravo R, Zimmermann M (1993b) Colocalization and covariation of the nuclcar c-JUN protcin with galanin in primary afferent neurons and with CGRP in spinal motoneurons following sciatic nerve transection. Mol Brain Res 17:147154.

Herdegen T, Sandkühler J, Gass P, Bravo R, Kiessling M, Zimmermann M (1993c) JUN, FOS, KROX and CREB transcription factor proteins in the rat cortex: basal expression and expression by $\mathrm{KCl}$-induced cortical spreading depression and bicuculline-induced seizures. J Comp Neurol 333:271-288.

Hirai SI, Ryseck RP, Mechta F, Bravo R, Yaniv M (1989) Characterisation of jun $\mathrm{D}$ : a new member of the jun proto-oncogene family. EMBO J 8:1433-1439.

Hope BT, Michael GJ, Knigge KM, Vincent SR (1991) Neuronal NADPH diaphorase is a nitric oxide synthase. Proc Natl Acad Sci USA 88:2811-2814.

Hsu JC, Bravo R, Taub R (1992) interactions among LRF-1, Jun B, c-Jun and c-Fos define a regulatory program in the Gl phase of liver regeneration. Mol Cell Biol 12:4654-4665.

Hyman C, Hofer M, Barde Y, Juhasz M, Yancopoulos GD, Squinto
SP, Lindsay RM (1991) BDNF is a neurotrophic factor for dopaminergic neurons of the substantia nigra. Nature 350:230-232.

Jenkins R, Hunt SP (1991) Long-term increase in the levels of c-jun mRNA and JUN protein-like immunoreactivity in motor and sensory neurons following axon damage. Neurosci Lett 129:107-110.

Jenkins R, O'Shea R, Hunt SP (1993) c-jun expression in substantia nigra neurons following striatal 6-hydroxydopamine lesions in the rat. Neuroscience 53:447-455.

Kalil K, Skene JHP (1986) Elevated synthesis of an axonally transported protein correlates with axon outgrowth in normal and injured pyramidal tracts. J Neurosci 6:2563-2570.

Kapitulnik J, Gelboin HV, Guengerich FP, Jacobowitz DM (1987) Immunohistochemical localization of cytochrome $\mathrm{P} 450$ in rat brain. Neuroscience 20:829-833.

Klatt P, Heinzel B, John M, Kastner M, Boehme E, Mayer B (1992) $\mathrm{Ca}^{++} /$calmodulin-dependent cytochrome $\mathrm{C}$ reductase activity of brain nitric oxide synthase. J Biol Chem 267:11374-11378.

Klein R, Nanduri V, Jing S, Lamballe F, Tapley P, Bryant S, CordonCordo C, Jones KR, Reichardt LF, Barbacid M (1991) The trkB tyrosine kinase is a receptor for brain-derived neurotrophic factor and neurotrophin-3. Cell 66:395-403.

Klein R, Lamballe F, Bryant S, Barbacid M (1992) The trkB tyrosine kinase is a receptor for neurotrophin-4. Neuron 8:947-956.

Knüsel B, Winslow JW, Rosenthal A, Burton LE, Seid DP, Nikolics K, Hefti $F$ (1991) Promotion of central cholinergic and dopaminergic neuron differentiation by brain-derived neurotrophic factor but not neurotrophin-3. Proc Natl Acad Sci USA 88:961-965.

Koh JY, Peters S, Choi DW (1986) Neurons containing NADPHdiaphorase are selectively resistant to quinolate toxicity. Science 234 73-76.

Kovary K, Bravo R (1991) Expression of different JUN and FOS proteins during the G0 to GI transition in mouse fibroblasts: in vitro and in vivo associations. Mol Cell Biol 11:2451-2459.

Kovary K, Bravo R (1992) Existence of different Fos/Jun complexes during the G0-to-G1 transition and during exponential growth in mouse fibroblasts: differential role of Fos proteins. Mol Cell Biol 12: $5015-5023$.

Kummer W, Fischer A, Mundel P, Mayer B, Hoba B, Philippin B, Preissler U (1992) Nitric oxide synthase in VIP-containing vasodilator nerve fibers in the guinca pig. Ncuroreport 3:653-655.

Leah J, Herdegen T, Kovary K, Bravo R (1991) Selective expression of JUN proteins following peripheral axotomy and axonal transport block in the rat: evidence for a role in the regeneration process. Brain Res 566:198-207.

Lemaire P, Relevant O, Bravo R, Charnay P (1988) Two mouse genes encoding potential transcription factors with identical DNA-binding domains are activated by growth factors in cultured cells. Proc Natl Acad Sci USA 85:4691-4695.

Lord KA, Hoffman-Liebermann B, Liebermann DA (1990) Complexity of the immediate early response of myeloid cells to terminal differentiation and growth arrcst includes ICAM-1, Jun-B and histone variants. Oncogene 5:387-396.

Lyon MJ, Stelzner DJ (1987) Tests of the regenerative capacity of tectal efferent axons in the frog, Rana pipiens. J Comp Neurol 255: 511-525.

Macgregor PF, Abate C, Curran T (1990) Direct cloning of leucine zipper proteins: Jun binds cooperating to the CRE with CRE-BP1. Oncogene 5:451-458.

Mayer B, John M, Böhme E (1990) Purification of a Ca ${ }^{2+} /$ calmodulindependent nitric oxide synthase from porcine cerebellum. FEBS Lett 277:215-219.

Mayer B, Klatt P, Böhme E, Schmidt K (1992) Regulation of neuronal nitric oxide and cyclic GMP formation by $\mathrm{Ca}^{++}$. J Neurochem 59: 2024-2029.

Mellström B, Achaval M, Montero D, Naranjo JR, Sassone-Corsi P (1991) Differential expression of the jun family members in rat brain. Oncogene 6:1959-1964.

Merlio JP, Ernfors P, Jaber M, Persson H (1992) Molecular cloning of rat trkC and distribution of cells expressing messenger RNAs for members of the trk family in the rat central nervous system. Neuroscience 51:513-532.

Mikucki SA, Oblinger MM (1991) Corticospinal neurons exhibit a novel pattern of cytoskeletal gene expression after injury. J Neurosci Res 30:213-225. 
Milbrandt J (1987) A nerve growth factor-induced gene encodes a possible transcriptional regulatory factor. Science 238:797-799.

Miller FD, Tetzlaff W, Bisby MA, Fawcett JW, Milner RJ (1989) Rapid induction of the major embryonic alpha-tubulin mRNA, T alpha-1, during nerve regeneration in adult rats. J Neurosci 9:14521463.

Moncada S, Palmer RMJ, Higgs EA (1991) Nitric oxide: physiology, pathophysiology and pharmacology. Pharmacol Rev 43:109-142.

Morris R, Southam E, Braid DJ, Garthwaite J (1992) Nitric oxide may act as a messenger between dorsal root ganglion neurones and their satellite cells. Neurosci Lett 137:29-32.

Nakabeppu Y, Ryder K, Nathans D (1988) DNA binding activities of three murine Jun proteins: stimulation by Fos. Cell 55:907-915.

Naranjo JR, Mellström B, Achaval M, Sassone-Corsi P (1991) Molecular pathways of pain: Fos/Jun-mediated activation of a noncanonical AP-1 site in the prodynorphin gene. Neuron 6:607-617.

Nieuwenhuys R, Geeraedts LMG, Veening JG (1982) The medial forebrain bundle of the rat. I. General introduction. J Comp Neurol 206:49-81.

Paxinos G, Watson C (1989) The rat brain in stereotaxic coordinates. Sydney: Academic.

Richardson PM, Issa VMK, Aguayo AJ (1984) Regeneration of long spinal axons in the rat. J Neurocytol 13:165-182.

Rutherfurd SD, Louis WJ, Gundlach AL (1992) Induction of c-jun expression in vagal motoneurons following axotomy. Neuroreport 3:465-468.

Ryder K, Nathans D (1988) Induction of protooncogene c-jun by serum growth factors. Proc Natl Acad Sci USA 85:8464-8467.

Ryseck R, Bravo R (1991) c-JUN, JUN B, and JUN D differ in their binding affinities to AP-1 and CRE consensus sequences: effect of FOS proteins. Oncogene 6:533-542.

Ryseck P, Hirai D, Yaniv M, Bravo R (1988) Transcriptional activation of c-jun during the $\mathrm{G} 0 / \mathrm{G} 1$ transition in mouse fibroblasts. Nature 334:535-537.

Sassone-Corsi P, Ransone LJ, Verma IM (1990) Cross-talk in signal transduction: TPA-inducible factor Jun/AP-1 activates cAMP-responsive enhancer elements. Oncogene 5:427-431.

Scheff SW, Benardo LS, Cotman CW (1980) Hydrocortisone administration retards axon sprouting in the rat dentate gyrus. Exp Neurol 68:195-201.

Scherer-Singler U, Vincent SR, Kimura H, McGeer EG (1983) Demonstration of a unique population of neurons with NADPH-diaphorase histochemistry. J Neurosci Methods 9:229-234.

Schlingensiepen KH, Gerdes W, Seifert W, Brysch W (1992) Role of Jun-B in neuronal differentiation. Eur J Neurosci [Suppl] 5:162.

Schnell L, Schwab ME (1990) Axonal regeneration in the rat spinal cord produced by antibody against myelin-associated neurite growth inhibitors. Nature 343:269-272.

Schüle R, Umesono K, Mangelsdorf DJ, Bolado J, Pike JW, Evans R (1990) Jun-Fos and receptors for vitamins $A$ and $D$ recognize a common response element in the human osteocalcin gene. Cell 61 : 497-504.

Schütte J, Viallet J, Nau M, Segal S, Fedorko J, Minna J (1989) Jun-B inhibits and c-fos stimulates the transforming and trans-activating activities of c-jun. Cell 59:987-997.

Seiger A, Olson L (1973) Late prenatal ontogeny of central monoamine neurons in the rat: fluorescence histochemical observations. Z Anat Entwicklungsgesch 140:281-318.

Seiger A, Olson L (1977) Quantitation of fiber growth in transplanted central monoamine neurons. Cell Tissue Res 179:285-316.

Sharp FR, Griffith J, Gonzalez MF, Sagar SM (1989) Trigeminal nerve section induces Fos-like immunoreactivity (FLI) in brainstem and decreases FLI in sensory cortex. Mol Brain Res 6:217-220.
Shemshedini L, Knauthe R, Sassone-Corsi P, Pornon A, Gronemeyer H (1991) Cell-specific inhibitory and stimulatory effects of Fos and Jun on transcription activation by nuclear receptors. EMBO .J 10: $3839-3849$.

Skene JHP (1989) Axonal growth-associated proteins. Annu Rev Neurosci $12: 127-156$

Sonnenberg JL, Macgregor-Leon PF, Curran T, Morgan J (1989a) Dynamic alterations occur in the levels and compositions of transcription factor AP-1 complexes after seizure. Neuron 3:359-365.

Sonnenberg JL, Rauscher FJ III, Morgan JI, Curran T (1989b) Regulation of proenkephalin by Fos and Jun. Science 246:1622-1625.

Sukhatme VP, Cao XM, Chang LC, Tsai-Morris CH, Stamenkovich D, Ferreira PCP, Cohen DR, Edwards SA, Shows TB, Curran T, LeBeau MM, Adamson ED (1988) A zinc finger-encoding gene coregulated with c-fos during growth and differentiation, and after cellular depolarisation. Cell 53:37-43.

Tetzlaff W, Alexander SW, Miller FD, Bisby MA (1991) Response of facial and rubrospinal neurons to axotomy: changes in mRNA expression for cytoskeletal proteins and GAP-43. J Neurosci 11:25282544.

Touray M, Ryan F, Jaggi R, Martin F (1991) Characterisation of functional inhibition of the glucocorticoid receptor by Fos/Jun. Oncogene 6:1227-1234.

Trejo J, Chambard JC, Karin M, Brown JH (1992) Biphasic increase in c-jun mRNA is required for induction of AP-1-mediated gene transcription: differential effects of muscarinic and thrombin receptor activation. Mol Cell Biol 12:4742-4750

Uemura Y, Kowall NW, Beal MF (1990) Selective sparing of NADPHdiaphorase-somatostatin-neuropeptide $Y$ neurons in ischemic gerbil striatum. Ann Neurol 27:620-625.

Veening JG, Swanson LW, Cowan MW, Nieuwenhuys R, Geeraedts LMG (1982) The medial forebrain bundle. II. An autoradiographic study of the topography of the major descending and ascending components. J Comp Neurol 206:82-108.

Verge VMK, Xu Z, Xu XJ, Wiesenfeld-Hallin Z (1992) Marked increase in nitric oxides synthase mRNA in rat dorsal root ganglia after peripheral axotomy: in situ hybridization and functional studies. Proc Natl Acad Sci USA 89:11617-11621.

Villegaz-Perez MP, Vidal-Sanz M, Bray GM, Aguayo AJ (1988) Influences of peripheral nerve grafts on the survival and regrowth of axotomized retinal ganglion cells in adult rats. J Neurosci 8:265-280.

Weiser M, Baker H, Wessel TC, Joh TH (1993) Axotomy-induced differential gene induction on neurons of the locus ceruleus and substantia nigra. Mol Brain Res 17:319-327.

Wictorin K, Brundin P, Gustavii B, Lindvall O, Björklund A (1990) Reformation of long axon pathways in adult rat central nervous system by human forebrain neuroblasts. Nature 347:556-558.

Wilkinson G, Bhatt S, Chavrier P, Bravo R, Charnay P (1989a) Segment-specific expression of a zinc finger gene in the developing nervous system of the mouse. Nature 337:461-464.

Wilkinson G, Bhatt S, Ryseck R, Bravo R (1989b) Tissue-specific expression of c-jun and jun $B$ during mouse development. Development 106:464-473.

Yu WHA, Yu MC (1983) Acceleration of the regeneration of the crushed hypoglossal nerve by testosterone. Exp Neurol 80:349-360.

Zhang XK, Wills KN, Husmann M, Hermann T, Pfahl M (1991) Novel pathway for thyroid hormone receptor action through interaction with jun and fos oncogene activities. Mol Cell Biol 11:6016-6025.

Zwiller J, Sassone-Corsi P, Kakazu K, Boynton AL (1991) Inhibition of PDGF-induced c-jun and c-fos expression by a tyrosine protein kinase inhibitor. Oncogene 6:219-221. 